\title{
Chronostratigraphy of the Barremian-Early Albian of the Maestrat Basin (E Iberian Peninsula): integrating strontium-isotope stratigraphy and ammonoid biostratigraphy
}

\author{
Telm Bover-Arnal ${ }^{a, *}$, Josep A. Moreno-Bedmar ${ }^{b}$, Gianluca Frijia ${ }^{c}$, Enric Pascual-Cebrian ${ }^{d}$, \\ Ramon Salas ${ }^{\text {a }}$ \\ ${ }^{a}$ Departament de Geoquímica, Petrologia i Prospecció Geològica, Facultat de Geologia, \\ Universitat de Barcelona, Martí i Franquès s/n, 08028 Barcelona, Spain \\ ${ }^{b}$ Instituto de Geología, Universidad Nacional Autónoma de México, Ciudad Universitaria, \\ Coyoacán, 04510 México D.F., Mexico \\ ${ }^{c}$ Institut für Erd- und Umweltwissenschaften, Universität Potsdam, Karl Liebknecht-Str. 24- \\ 25, Potsdam-Golm 14476, Germany \\ ${ }^{d}$ GeoScience Limited, Falmouth Business Park, Bickland Water Road, Falmouth TR11 4SZ, \\ $U K$ \\ * Corresponding author. \\ E-mail address: telm.boverarnal@ub.edu (T. Bover-Arnal).
} A

Abstract. A revised chronostratigraphy of the Barremian-Early Albian sedimentary record of the Maestrat Basin (E Iberian Peninsula) is provided based on a comprehensive synthesis of previous biostratigrahic data, a new ammonoid finding and numerical ages derived from ${ }^{87} \mathrm{Sr} /{ }^{86} \mathrm{Sr}$ values measured on shells of rudists, oysters and brachiopods. The succession, which comprises eight lithostratigraphic formations, is arranged into six major transgressiveregressive sequences and plotted against numerical ages, geomagnetic polarity chrons, ammonoid zones and the stratigraphic distribution of age-diagnostic ammonoids, orbitolinid foraminifera and rudist bivalves. The oldest lithostratigraphic unit sampled, the marine Artoles Formation, is Early to Late Barremian. Above, the dinosaur-bearing deposits of the Morella Formation and its coastal to shallow-marine equivalent, the Cervera del Maestrat Formation, are of Late Barremian age and span at least part of the Imerites giraudi ammonoid zone. ${ }^{87} \mathrm{Sr} /{ }^{86} \mathrm{Sr}$ ratios from oyster shells in the upper part of the overlying marine Xert Formation are consistent with a latest Barremian-earliest Aptian age, while an ammonite belonging to the Late Barremian Martelites sarasini Zone was collected within the lowermost 
part of this latter formation. The Barremian-Aptian boundary is tentatively placed close above the base of the succeeding transgressive marls of the Forcall Formation by analogy with nearby Tethyan basins, where major transgressive records contain latest Barremian ammonoids in their basal parts. The rest of the Forcall Formation and the platform carbonates of the Villarroya de los Pinares Formation are of Early Aptian age. The transition from the Barremian into the Aptian occurred in the course of a wide transgression, which was accompanied by the proliferation of Palorbitolina lenticularis. This transgressive event drowned Late Barremian carbonate platforms (Xert Formation) throughout the basin. Extensive carbonate platforms (Villarroya de los Pinares Formation) recovered coevally with a post-OAE1a late Early Aptian major regression of relative sea level. The last lithostratigraphic unit analyzed, the marine Benassal Formation, spans the terminal Early Aptian-Late Aptian interval. Based on ammonite distributions, the lower part of the overlying coastal to continental coal-bearing Escucha Formation is Early Albian in age. This improved chronostratigraphic knowledge allows a more precise correlation of the sedimentary record studied with other coeval successions worldwide.

Key words. Strontium-isotope stratigraphy, Geochronology, Biostratigraphy, Ammonoids, Early Cretaceous, Iberian Chain, Tethys

\section{Introduction}

In the Maestrat Basin (Fig. 1), the boundary between the Barremian and the Aptian stages has been classically placed within the Artoles Formation (boundary A1 in Fig. 2; e.g., Salas 1987, Salas et al. 1995, 2001, Aurell and Vennin 2001, Liesa et al. 2006, Embry et al. 2010) or at the limit between the Artoles and the Morella/Cervera del Maestrat formations 
(boundary A2 in Fig. 2; e.g., Gàmez et al. 2003, Salas et al. 2005, Moreno-Bedmar et al. 2009, 2010, Bover-Arnal et al. 2009, 2010). The stratigraphic calibration of this boundary was mainly based on charophyte, ostracod and/or benthic foraminifera biostratigraphic data (e.g., Canérot et al. 1982, Salas et al. 1995) and geomagnetic polarity (e.g., Salas et al. 2005). However, and besides the above-mentioned chronostratigraphic discrepancy between studies, Canérot et al. (1982) and López Llorens (2007) already noted that the stratigraphic position of the Barremian-Aptian boundary in the Maestrat Basin was not successfully established yet. Thus, while depicting the Barremian/Aptian boundary at the limit between the Morella (or Cervera del Maestrat) and Xert formations, Canerot et al. (1982, Fig. 6.1, p. 277), in their descriptions of lithostratigraphic units, by contrast, give a terminal Barremian or earliest Aptian age for the Morella Formation (p. 285) and a terminal Barremian to earliest Aptian time span for its coastal to marine equivalent the Cervera del Maestrat Formation (p. 284). On the other hand, López Llorens (2007) found an Argvethites sp. (genus determination modified in Garcia et al. 2014), a Late Barremian ammonite belonging to the Imerites giraudi Zone, within the marine-influenced deposits of the uppermost part of the Morella Formation, thus ruling out the Early Aptian age classically assumed for this lithostratigraphic unit.

Later on, Moreno-Bedmar and Garcia (2011) put forward the hypothesis that the Barremian-Aptian boundary was located at the lowermost part of the marls of the Forcall Formation (boundary B in Fig. 2). This supposition was founded on the recognition of the Deshayesites oglanlensis ammonoid Zone and the Subzone Deshayesites luppovi at the lower part of the marls of the Forcall Formation. Moreno-Bedmar and Garcia (2011) also noted that the Organyà Basin in north-eastern Spain and the Provençal Platform in south-eastern France recorded a major transgressive event starting in the latest Barremian that would then be analogous to the deposition of the hemipelagic marls of the Forcall Formation in the Maestrat Basin (E Spain). Since then, Garcia et al. (2014) and Villanueva-Amadoz et al. (2014) have 
attempted to test this hypothesis by reviewing the literature and providing new data on the Barremian-Aptian ammonite biostratigraphy of the Maestrat Basin and by studying the palynological content of the Morella Formation. Even though neither of these two works is conclusive, they lend support to the Moreno-Bedmar and Garcia (2011) hypothesis. Garcia et al. (2014) identified the species Deshayesites antiquus Bogdanova and Deshayesites sp. cf. oglanlensis Bogdanova in the lower, non-basal part of the marls of the Forcall Formation. These species are characteristic of the lower part of the Deshayesites oglanlensis Zone, which is the first Aptian ammonoid Zone (Fig. 3; Reboulet et al. 2011, 2014). Villanueva-Amadoz et al. (2014) record the dinoflagellate cysts Subtilisphaera terrula, Florentinia mantelli and Oligosphaeridium abaculum, which indicate a Barremian age, from the base of the Morella Formation. Villanueva-Amadoz et al. (2014) also recognize the pollen type Stellatopollis sp. in the upper part of the Morella Formation and indicate that possibly this formation may be as old as Late Barremian.

Using strontium-isotope stratigraphy and new ammonite biostratigraphic data the present study conclusively locates the Barremian-Aptian boundary, while also calibrating the age of the Barremian-Early Albian lithostratigraphic units of the Maestrat Basin. Strontiumisotope stratigraphy is today a well-established, proven and widely adopted chemostratigraphic method, which allows derivation of numerical ages from known past changes in the ${ }^{87} \mathrm{Sr} /{ }^{86} \mathrm{Sr}$ ratio of seawater (e.g., Steuber 1999, 2001, 2003a, b, McArthur et al. 2001, 2012, McArthur and Howarth 2004, Steuber et al. 2005, Frijia and Parente 2008, Bodin et al. 2009, Burla et al. 2009, Boix et al. 2011, Huck et al. 2011, Steuber and Schlüter 2012, Wagreich et al. 2012, Williamson et al. 2012, Jaramillo-Vogel et al. 2013, Bonilla-Rodríguez et al. 2014, Pascual-Cebrian 2014, Frijia et al. 2015). The resulting numerical ages derived from ${ }^{87} \mathrm{Sr} /{ }^{86} \mathrm{Sr}$ values obtained from brachiopod, rudist and oyster shells collected in selected stratigraphic intervals of the Barremian-Early Albian sedimentary succession of the Maestrat 
109 Basin are plotted against lithostratigraphic units, major transgressive-regressive sequences of

110 relative sea level recorded in the basin, ammonoid zones, geomagnetic polarity chrons, and 111 ammonite, orbitolinid and rudist occurrences (Fig. 3). The results are complemented with

112 numerical ages derived from ${ }^{87} \mathrm{Sr} /{ }^{86} \mathrm{Sr}$ ratios measured in rudist shells from the western 113 Maestrat Basin by Pascual-Cebrian (2014).

114 Therefore, besides constraining the stratigraphic position of the Barremian-Aptian 115 boundary in the Maestrat Basin, the resulting chronostratigraphic framework (Fig. 3) allows 116 us: i) to establish the age of the dinosaur and other vertebrate records found in the Morella 117 and Xert formations (e.g., Yagüe et al. 2003, Canudo et al. 2008a, b, Jorquera-Grau et al. 118 2009, Pérez-García et al. 2009, 2014, Gasulla et al. 2011a, 2011b, 2012); ii) to date the major 119 Barremian-Early Albian transgressive-regressive trends of relative sea level and the episodes 120 of carbonate platform development, subaerial exposure and drowning in the basin; iii) to give 121 a more precise correlation of the sedimentary record studied with other coeval successions worldwide, and iv) to test the numerical-age calibrations of Tethyan Barremian-Early Albian 123 ammonoid, orbitolinid and rudist species ranges and the biostratigraphic correlation between 124 their different zonations. Figure 1 (width of page) near here

\section{Geological setting} margin of the Iberian plate that developed on account of tectonic extension linked to the 
134 Jurassic) to the Albian (Early Cretaceous), the Maestrat Basin was structured into seven sub-

135 basins: Aliaga, El Perelló, Galve, Morella, Oliete, Penyagolosa and Salzedella (Salas and

136 Guimerà 1996; Fig. 1B). Throughout the Barremian-Early Albian time interval reviewed in

137 this paper, up to $2 \mathrm{~km}$-thick continental to hemipelagic mixed carbonate-siliciclastic

138 sedimentary successions were deposited within these sub-basins (Canérot et al. 1982; Salas

139 1987). Later on, during the Paleogene-Early Miocene, and due to the collision between the

140 Iberian and European plates in the course of the Alpine orogeny, the Maestrat Basin was 141 inverted and gave rise to the eastern part of the Iberian Chain (E Iberian Peninsula; Fig. 1A)

142 (Salas et al. 2001). Figure 2 (width of column) near here

\subsection{Barremian-Early Albian lithostratigraphy}

The Barremian-Early Albian sedimentary record from the Maestrat Basin can be subdivided into eight lithostratigraphic units with the rank of formations. These formations

150 are named from oldest to youngest as Artoles, Cervera del Maestrat, Morella, Xert, Forcall, 151 Villarroya de los Pinares, Benassal and Escucha (Fig. 3; Canérot et al. 1982, Salas 1987, Salas et al. 1995, 2001).

The marine Artoles Formation (Figs 3 and 5A) is mainly characterized by an

154 alternation of marls, sandy limestones and limestones rich in oysters (Salas 1987, Salas et al. 155 1995, 2001, Caja 2004). Above, fluviatile red clays and sandstones associated with vertebrate 156 fossils constitute the Morella Formation (Figs 3 and 5A-B; Canérot et al. 1982, Salas 1987, 157 Salas et al. 1995, Gàmez et al. 2003). Bioclastic and sandy limestones in the upper part of the 158 Morella Formation indicate punctuated episodes of coastal to marine influence (Figs 3 and 
5A-B; Canérot et al. 1982). The Morella Formation passes laterally to the mixed carbonate-

160 siliciclastic coastal to shallow-marine deposits of the Cervera del Maestrat Formation (Figs 3, 161 5C and 6A; Canérot et al. 1982, Salas 1987, Salas et al. 1995). The overlying Xert Formation

162 (Figs 3, 5A, 6 and 7A) consists of an alternation of marine sandstones, sandy limestones and 163 marls, which evolve into massive limestones containing abundant orbitolinids in the upper 164 part of the formation (Canérot et al. 1982, Salas 1987, Salas et al. 1995, Vennin and Aurell 165 2001, Bover-Arnal et al. 2010, Embry et al. 2010). The Forcall Formation (Figs 3, 6 and 7A-C) is mainly made up of basin marls with interbedded marly limestones, silty limestones, sandy limestones and limestones characterized by fossil biota such as ammonoids and Palorbitolina lenticularis (Canérot et al. 1982, Salas 1987, Salas et al. 1995, Clariana 1999, Moreno-Bedmar et al. 2010a). The four Early Aptian ammonoid zones namely, Deshayesites oglanlensis, Deshayesites forbesi, Deshayesites deshayesi and Dufrenoyia furcata, are recorded within this formation (Fig. 3; MorenoBedmar et al. 2010a, Garcia et al. 2014). The C-isotope shifts linked to the Early Aptian oceanic anoxic event (OAE1a) have been located at the upper part of the Deshayesites forbesi

174 Zone within the Forcall Formation (Fig. 3; Moreno-Bedmar et al. 2009a, Bover-Arnal et al.

175 2010, 2011b, Cors et al. 2015). The position of the OAE1a within the Deshayesites forbesi 176 Zone (and not within the Deshayesites deshayesi Zone as often reported by other workers, 177 notably in the Vocontian Basin in France, e.g., Moullade et al. 2015) is not related to any 178 dischronism of the OAE1a or to a later first appearance datum of Deshayesites deshayesi in 179 the Maestrat Basin, but rather to a disagreement between authors about the taxonomic 180 identification of Deshayesites deshayesi (see Moreno-Bedmar et al. 2009, 2014). The succeeding lithostratigraphic unit, the Villarroya de los Pinares Formation (Figs 3, 1826 and 7A, C; Canérot et al. 1982, Salas 1987, Salas et al. 1995, Clariana 1999, Clariana et al. 183 2000), is characterized by sandy limestones, oolitic, peloidal and skeletal packstones and 
184 grainstones, and platform carbonates with floatstone to rudstone textures containing rudist

185 bivalves and corals. Locally, the Villarroya de los Pinares Formation is also constituted by 186 mudstones with ammonites, planktic foraminifera and sponge spicules. The Villarroya de los

187 Pinares Formation passes basinwards to the marls of the Forcall Formation (Fig. 3; see Bover188 Arnal et al. 2009).

189 The Benassal Formation consists of an alternation of marly intervals containing 190 bivalves, gastropods and locally, scleractinian corals, and platform carbonates dominated by 191 rudist bivalves, colonial corals and nerineid gastropods (Figs 3, 6A, 7A, C-D and 8A-B; Salas 192 1987, Tomás et al. 2008, Bover-Arnal et al. 2010, Martín-Martín et al. 2013, 2015, Gomez193 Rivas et al. 2014). The uppermost part of the Benassal Formation is formed by ferruginous 194 ooid grainstones, sandstones, sandy limestones and clays indicating a progressive shallowing 195 of the depositional environment (Figs 3, 6A and 8B; Canérot et al. 1982, Salas 1987, Bover196 Arnal et al. 2010). This formation registered the uppermost part of the Dufrenoyia furcata 197 Zone at its base (Fig. 3; Moreno-Bedmar et al. 2012, Bover-Arnal et al. 2014, Garcia et al. 198 2014). Ammonoid specimens belonging to the Epicheloniceras martini, Parahoplites 199 melchioris and Acanthoplites nolani zones have been found along the Benassal Formation 200 (Fig. 3; Weisser 1959, Moreno-Bedmar et al. 2010a, Martín-Martín et al. 2013, Garcia et al. $2012014)$.

Above, the Escucha Formation mainly corresponds to an alternation of clays, coal 203 levels and sandstones (Figs 3 and 8C; Aguilar et al. 1971, Pardo 1979, Pardo and Villena 204 1979, Canérot et al. 1982, Querol 1990, Querol et al. 1992). Locally, the limit between the 205 Benassal and Escucha formations corresponds to an erosional unconformity (Canérot et al. 206 1982, Salas 1987, Querol et al. 1992, Salas et al. 1995). In the depocentre of the Maestrat 207 Basin, which is located in the northeastern part of the Salzedella sub-basin (Fig. 1B), the 
lower part of the Escucha Formation was dated by means of ammonoids as earliest Albian

(Fig. 3; Moreno-Bedmar et al. 2008, Garcia et al. 2014).

210

\section{Materials and methods}

\subsection{Terminology}

In this paper, the stratigraphic terminology of time-rock units and geologic time units

218 is unified following Zalasiewicz et al. (2004). Accordingly, the paper uses "early" and "late",

219 but not "lower" and "upper", to define both chronostratigraphical and geochronological terms.

\subsection{Lithostratigraphic units and localities sampled}

Seven samples for strontium-isotope stratigraphy were collected from three different stratigraphic levels within the Artoles Formation in the Salzedella sub-basin (Fig. 1B). Two brachiopods, pieces A1-A and A1-B (Fig. 3 and Table 1A), and two oyster shells, specimens A2-A and A2-B (Fig. 3 and Table 1A), were sampled in the lower-middle part of this lithostratigraphic unit in the Corral d'en Parra section (UTM coordinates: X=31T 263453, 228 Y=4482816; see Salas 1987), in the outskirts of the town of Sant Mateu (Comarca of El Baix 229 Maestrat). In addition, three oyster specimens, A3-A, A3-B and A3-C (Fig. 3 and Table 1A), 230 were taken at the upper part of the Artoles Formation cropping out along the road N-232, in 231 Mas del Regall (UTM coordinates: $X=31 T$ 257351, $Y=4489393$; see Salas 1987), in the 232 surroundings of the town of Xert (Comarca of El Baix Maestrat). 
234 collected in the lower part of the Cervera del Maestrat Formation in the Salzedella sub-basin 235 (Fig. 1B). The sampling locality corresponds to Mas del Regall section (UTM coordinates: $\mathrm{X}=31 \mathrm{~T}$ 257612, $\mathrm{Y}=4489753$; see Salas 1987), which crops out $2.2 \mathrm{~km}$ to the west of the town of Xert (Comarca of El Baix Maestrat).

The two oyster shells, specimens X1-A and X1-B (Fig. 3 and Table 1 A), sampled to calibrate the age of the Xert Formation, come from the Salzedella sub-basin (Fig. 1B). These low-Mg calcite pieces were collected in the upper part of this lithostratigraphic unit exposed along the forest road (UTM coordinates: $X=31 T$ 258579, $Y=4490741$; see Salas 1987) that goes from the town of Xert (Comarca of El Baix Maestrat) to the Turmell Range (Comarca of 243 Els Ports).

Finally, three rudist shells, samples B1-A, B1-B and B1-C (Fig. 3 and Table 1A), were 245 plucked from the Benassal Formation in the Morella sub-basin (Fig. 1B). The stratigraphic 246 level sampled corresponds to the upper part of transgressive incised valley-fill deposits, which 247 are found at the Mola d'en Camaràs (UTM coordinates: $X=30 T$ 740119, Y=4503220.80; see 248 Bover-Arnal et al. 2014), $3 \mathrm{~km}$ to the northeast of the town of El Forcall (Comarca of Els 249 Ports).

\subsection{Strontium-isotope stratigraphy}

The analytical and chronostratigraphic data presented in Table 1A were obtained from 25415 samples collected for this study. These results were integrated with the dataset of Pascual255 Cebrian (2014) (Table 1B) who performed strontium-isotope stratigraphic analyses on 5 256 rudist shells collected in the Forcall, Villarroya de los Pinares and Benassal formations in the western Maestrat Basin (Galve sub-basin; Fig. 1B). In the present work, the samples studied 
by Pascual-Cebrian (2014) have been renumbered for simplicity: F1 = LC-Sr-1; V1 = LSCSr-3; V2 = LSC-Sr-1; V3 = Mi-Sr-2; B2 = BC-Sr-1 (Fig. 3 and Table 1B). Sample F1 was collected within the Lithocodium aggregatum-bearing horizon found in the Forcall Formation cropping out in Las Cubetas section (Fig. 1B; UTM coordinates: X=30T 694192.131, $\mathrm{Y}=4504314.076$; see Bover-Arnal et al. 2010, 2011b for sample locality details). Samples V1 and V2 come from the lower part of the Villarroya de los Pinares Formation in La Serna (Fig. 1B; UTM coordinates: X=30T 693819.913, Y=4490421.394; see Bover-Arnal et al. 2015 for location of samples). Specimen V3 was collected in the upper part of the Villarroya de los Pinares Formation in Las Mingachas locality (Fig. 1B; UTM coordinates: X=30T 693684.184, Y=4494385.624; see Bover-Arnal et al. 2009 for sample locality details). Specimen B2 was sampled in the lower part of the Benassal Formation in the Las Corralizas section (Fig. 1B; UTM coordinates: X=30T 693993.535, Y=4492353.315; see Bover-Arnal et al. 2010 for location of sample). The selection process and preparation of these samples, as well as the methodology followed to obtain the ${ }^{87} \mathrm{Sr} /{ }^{86} \mathrm{Sr}$ ratios and derived numerical ages, are described in Pascual-Cebrian (2014).

The new analytical data were measured in biotic low Mg-calcite (mainly oysters and a 274 few rudists and brachiopods) coming from 4 different localities (Figs. 1B and 3; Table 1A).

275 Whenever possible, multiple samples were collected from each stratigraphic level, in order to test the internal consistency of the data. Laboratory preparation of the biotic low Mg-calcite 277 for analysis followed the method described in Frijia and Parente (2008) and Boix et al. 278 (2011). Rock samples and larger shells were cut to produce $0.5-2 \mathrm{~cm}$-thick slabs. These were 279 ground and polished on all sides in order to eliminate superficial contamination. Isolated 280 shells and fragments were washed, through repeated cycles, in an ultrasound bath filled with a 281 solution of deionised water and $\mathrm{H}_{2} \mathrm{O}_{2} 5 \%$ at $50{ }^{\circ} \mathrm{C}$ for 5 minutes to remove adhering clay 282 minerals and then dried at room temperature. Furthermore, some shell was treated for 20 to 45 
seconds in HCL $1 \mathrm{M}$, to eliminate calcite overgrowths, and then rinsed carefully with 284 deionised water. As a final step all the samples were washed ultrasonically in a bath of 285 ultrapure water (milli-Q water) for 3 minutes and then dried in a clean environment. All the 286 samples (rock slabs and isolated shell fragments) were then passed through a complete 287 petrographic screening (optical microscope and scanning electron microscope) to assess the 288 preservation of the original shell microstructure.

The elemental ( $\mathrm{Mg}, \mathrm{Sr}, \mathrm{Mn}$ and Fe) composition of the shells was analysed as a further screening step. The micritic matrix of some samples was also analysed in order to get deeper insight into the diagenetic processes. Samples for geochemical analyses were obtained by 292 microsampling, under the microscope, of selected areas of polished slabs and shell fragments 293 with a hand-operated microdrill equipped with 0.3 to $0.5 \mathrm{~mm} \varnothing$ tungsten drill bits. Two splits 294 of each sample were prepared. The first split was used for the ICP-AES analysis of $\mathrm{Mg}, \mathrm{Sr}, \mathrm{Fe}$ 295 and Mn concentration. The second split of the powdered samples was used for strontium296 isotope analysis. Geochemical analyses were performed at the Institute for Geology, 297 Mineralogy and Geophysics of the Ruhr-University (Bochum, Germany). After strontium 298 separation by standard ion-exchange methods, strontium-isotope ratios were analyzed on a 299 Finnigan MAT 262 thermal-ionisation mass spectrometer and normalized to an ${ }^{86} \mathrm{Sr} /{ }^{88} \mathrm{Sr}$ value 300 of 0.1194 . The mean value of the USGS EN-1 (modern seawater) standards run together with 301 the samples analysed for this study is $0.709174 \pm 0.000006(2$ s.e., $\mathrm{n}=4)$. The ${ }^{87} \mathrm{Sr} /{ }^{86} \mathrm{Sr}$ ratios 302 of the samples were adjusted to a value of 0.709175 for the USGS EN-1 standard, to be 303 consistent with the normalisation used in the compilation of the look-up table of McArthur et 304 al. (2001; version 4: 08/04). A mean value was calculated when more than one sample was 305 available for one stratigraphic level. The precision of the ${ }^{87} \mathrm{Sr} /{ }^{86} \mathrm{Sr}$ mean value for each 306 stratigraphic level is given as 2 s.e. of the mean when the number of samples (n) is $\geq 4$. When $307 \mathrm{n}<4$, the precision is considered to be not better than the average precision of single 
measurements and is calculated from the standard deviation of the mean value of the

309 standards run with the samples $( \pm 0.000013$ for $n=1, \pm 0.000009$ for $n=2$ and \pm 0.000007 for $310 \mathrm{n}=3)$.

The numerical ages of the samples analysed in this study were derived from the lookup table of McArthur et al. (2001, version 4: 08/04, see procedure regarding age calculation in Frijia et al. 2015), which is tied to the Geological Time Scale of Gradstein et al. (2004;

314 hereinafter GTS2004). Minimum and maximum ages were obtained by combining the statistical uncertainty ( 2 s.e.) of the mean values of the Sr-isotope ratios of the samples with the uncertainty of the seawater curve. The numerical ages were then translated into chronostratigraphic ages and corresponding standard ammonite biozones by reference to the 318 GTS2004.

\subsection{Transgressive-regressive sequence-stratigraphic model}

The transgressive-regressive sequence-stratigraphic framework is based on the recognition of subaerial unconformity surfaces, maximum flooding surfaces, maximum

324 flooding zones, transgressive surfaces, changes in stacking patterns of lithostratigraphic units and the observed facies succession at the scale of formations by Pardo (1979), Pardo and Villena (1990), Salas (1987), Canérot et al. (1982), Querol (1990), Querol et al. (1992),

327 Vennin and Aurell (2001), Bover-Arnal et al. (2009, 2010, 2011b, 2014, 2015), Embry et al. 328 (2010) and Martín-Martín et al. (2013). Previous sequence-stratigraphic analyses carried out 329 in the basin were also taken into account (e.g., Salas 1987, Salas et al. 2001, Vennin and 330 Aurell 2001, Bover-Arnal et al. 2009, 2010, 2011a, 2014, 2015, Embry et al. 2010, Martín331 Martín et al. 2013). See Catuneanu et al. (2009, 2011) for the conceptual background of the 332 transgressive-regressive sequence-stratigraphic method. 


\section{Preservation of the original Sr-isotope signal}

The first and most critical step in order to correctly perform strontium-isotope

stratigraphy is to evaluate the preservation of the analysed material. Diagenetic processes can alter significatively the original marine ${ }^{87} \mathrm{Sr} /{ }^{86} \mathrm{Sr}$ signal leading to a wrong age derivation/calculation. The diagenetic screening approach used in this study to assess the preservation of the analysed fossils followed that described in similar previous works (Steuber et al. 2005, Boix et al. 2011, Frijia and Parente 2008, Frijia et al. 2015).

Analysis of the concentration of some major and trace elements is a powerful tool to estimate the degree of alteration of a bioclastic sample. In this respect, a pattern of lower $\mathrm{Sr}$ concentrations, and higher $\mathrm{Mn}$ and Fe concentrations and ${ }^{87} \mathrm{Sr} /{ }^{86} \mathrm{Sr}$ ratios has been commonly associated with a significant degree of diagenetic alteration in multicomponent studies in carbonates (Brand and Veizer 1980, Al-Aasm and Veizer 1986, Brand et al. 2012). shells and matrix (mixture of pristine and diagenetic phases) both showing $\mathrm{Fe}$ and $\mathrm{Mn}$ 354 concentrations quite variable with respect to Sr (Table 1A). Frijia et al. (2015) pointed out that relatively high $\mathrm{Fe}$ and $\mathrm{Mn}$ concentrations are not always indicators of diagenetic processes. High Fe and Mn concentrations occur in shells rather due to contamination from surface oxide coatings than due to recrystallization or incorporation. On the other hand, 
relatively low Fe and Mn concentrations have been found also in diagenetic calcite (Steuber et al. 2005, Frijia and Parente 2008, Boix et al. 2011, Vicedo et al. 2011, Frijia et al. 2015). The micritic matrix samples analyzed exhibit the highest values for these two elements (Fe up to 7812 ppm and Mn up to 492 ppm; Table 1A), suggesting diagenetic fluids rich in Fe and Mn. Therefore, even if we mainly rely on Sr concentration as the prime criterion of diagenetic screening ( $\mathrm{Sr}>750 \mathrm{ppm}$ as indicated in Frijia et al. 2015), we also use concentrations of $\mathrm{Fe}<$ $250 \mathrm{ppm}$ and $\mathrm{Mn}<50 \mathrm{ppm}$ as conservative threshold values to help discriminating between samples which have retained their pristine isotopic composition and samples that have incorporated significant amounts of diagenetic $\mathrm{Sr}$ (see references in Frijia et al. 2015). and the Sr-isotope value of the different shells and matrix from the same level. The data show that the micritic matrix has lower $\mathrm{Sr}$ concentrations and significantly higher $\mathrm{Sr}$-isotope values than pristine shells. This is the trend expected for diagenetic alteration or for mixing of pristine and diagenetic material (Banner 1995). In general, in the dataset presented, different shells from the same bed, most of which passed the steps of the diagenetic screening, have ${ }^{87} \mathrm{Sr} /{ }^{86} \mathrm{Sr}$ ratios within a very narrow range, slightly higher than the analytical precision (2 s.e. 0.000007). This internal consistency of the Sr-isotope ratios of different samples from the same level can be considered as strong evidence that the samples used for strontium-isotope stratigraphy retained their original marine Sr-isotope signature (McArthur 1994, McArthur et al. 2006, Brand et al. 2011). Sample B1-B has a Sr concentration below the threshold here adopted whereas for sample B1-C we could not get enough material to perform both ICP and Sr-isotope 380 measurements. However, these samples exhibit ${ }^{87} \mathrm{Sr} /{ }^{86} \mathrm{Sr}$ ratios very similar to that from sample B1-A and significantly lower than the isotopic ratio of the micritic matrix enclosing 382 the shells (Table 1A). Accordingly, these shells are considered to preserve the original 
${ }^{87} \mathrm{Sr} /{ }^{86} \mathrm{Sr}$ signal and are used for strontium-isotope stratigraphy. On the other hand, samples

384 C1-A, C1-B and A3-A were discarded despite of their high Sr concentration because of their

385 Fe and Mn values, which were above the chosen limit and mainly because their ${ }^{87} \mathrm{Sr} /{ }^{86} \mathrm{Sr}$

386 ratios were found to be considerably higher than the ratio measured in the other samples from

387 the same stratigraphic level (Table 1A). Finally, sample C1-C was used for strontium-isotope

388 stratigraphy despite its Fe and Mn concentrations above the indicated threshold since this

389 sample yielded the lowest ${ }^{87} \mathrm{Sr} /{ }^{86} \mathrm{Sr}$ ratio of the level (Table 1A). However, it cannot be ruled

390 out that the original ${ }^{87} \mathrm{Sr} /{ }^{86} \mathrm{Sr}$ of this sample could have been, in part, modified by diagenesis

391 and therefore the derived SIS ages for this level are treated in a conservative way (see below).

5. Strontium ratios and derived numerical ages of the samples

The ${ }^{87} \mathrm{Sr} /{ }^{86} \mathrm{Sr}$ values obtained from low-Mg calcite shells collected for the present study in the Maestrat Basin range from $0.707488 \pm 0.000009$ down to $0.707310 \pm 0.000007$ (Table 1A). These values translate respectively into numerical ages of 127.49-128.33 Ma $(+1.44 /-0.88)$ and $118.93 \mathrm{Ma}(+0.73 /-0.7)$, which constrain the age of the specimens analysed within the Barremian-early Late Aptian time interval (GTS 2004). For description of the Srisotopic data and the derived numerical ages presented in Table 1B refer to Pascual-Cebrian (2014).

403 its lower-middle part and sample A3 from its upper part). The Sr-isotope ratios of the two 404 sampled intervals are identical $(0.707488 \pm 0.000009)$ and translate into a numerical age of 405 127.49-128.33 Ma (+1.44/-0.88) corresponding to the early Late Barremian (Fig. 3 and Table 1A). However, if the total age range is considered (126.61-129.77 Ma), the age of the samples spans almost the whole Barremian (see GTS 2004). Such a large age interval is due to the fact 
that the Sr-isotope curve from the middle Early Barremian to the early Late Barremian is 409 characterized by fairly stable values (e.g., Bodin et al. 2009; Mutterlose et al. 2014). In 410 southeastern France, Bodin et al. (2009) report mean ${ }^{87} \mathrm{Sr} /{ }^{86} \mathrm{Sr}$ ratios of 0.707488 to 0.707506 411 for this interval (Kotetishvilia Nicklesi through Toxancyloceras vandenheckii Tethyan 412 ammonite zones). These values are slightly higher than those reported for the Early Barremian 413 to the early Late Barremian by McArthur et al. (2004) from the Boreal realm ( 0.707475 in 414 the Early Barremian Hoplocrioceras rarocinctum Zone to 0.707485 in the lowermost early 415 Late Barremian Parancyloceras elegans Zone). Furthermore, as highlighted by Mutterlose et 416 al. (2014), an offset between the Tethyan and Boreal Sr-isotopic curves from the middle Early 417 Barremian to the early Late Barremian makes it difficult to use strontium-isotope stratigraphy 418 for precise age calculation across this interval. However, if we consider the absolute Sr419 isotopic values of our samples as a tool of correlation, they are indistinguishable from those of 420 Bodin et al. (2009) and McArthur et al. (2004) constraining the age of our samples A to the 421 middle Early-early Late Barremian. The Artoles Formation in the Salzedella sub-basin (Fig. 422 1B; depocentre of the Maestrat Basin) is about 750 m-thick. Samples A1 and A2 were 423 collected in the lower-middle part of this formation in the depocentre of the basin, about 300 424 meters above the last Hauterivian ammonite. This would suggest a middle/late Early 425 Barremian age for samples A1 and A2. On the other hand, sample A3 collected in the upper 426 part of the Artoles Formation is ascribed to the early Late Barremian. The ${ }^{87} \mathrm{Sr} /{ }^{86} \mathrm{Sr}$ ratio of $0.707466 \pm 0.000013$ for samples $\mathrm{C} 1$ from the lower part of the 428 Cervera del Maestrat Formation translates into an age of 126.24 Ma (+0.77/-0.62) (Fig. 3 and 429 Table 1A). This numerical age is coincident with the Late Barremian by reference to the 430 GTS2004. Furthermore, the ${ }^{87} \mathrm{Sr} /{ }^{86} \mathrm{Sr}$ values from our samples $\mathrm{C} 1(0.707466,0.707513$ and 431 0.707565; Table 1A) are similar to the mean ${ }^{87} \mathrm{Sr} /{ }^{86} \mathrm{Sr}$ values reported by Bodin et al. (2009) 432 in southeastern France for the Late Barremian Gerhardtia Sartusiana to Imerites giraudi 
ammonite zones (0.707466 and 0.707452 , respectively). However, owing to the concerns raised in the previous section, the mean ${ }^{87} \mathrm{Sr} /{ }^{86} \mathrm{Sr}$ ratio of samples $\mathrm{C} 1$ is regarded as a maximum age estimate. In fact, considering the marine Sr reference curve of McArthur et al. (2001) for the Barremian-Aptian interval, any lower ${ }^{87} \mathrm{Sr} /{ }^{86} \mathrm{Sr}$ ratio from this stratigraphic level than that of sample C1-C would translate into younger ages.

The ${ }^{87} \mathrm{Sr} /{ }^{86} \mathrm{Sr}$ value of $0.707425 \pm 0.000013$ obtained from the upper part from the Xert Formation (samples X1), gives an age of 124.94 Ma (+0.59/-0.64) (Fig. 3 and Table 1A). This numerical age and the associated minimum to maximum range are in accordance with a latest Barremian-earliest Aptian age (GST2004).

The youngest low-Mg calcite shells analysed are those collected in the Benassal Formation (samples B1). Sr-isotopic data obtained for this latter lithostratigraphic unit yield a mean ${ }^{87} \mathrm{Sr} /{ }^{86} \mathrm{Sr}$ value of $0.707310 \pm 0.000007$, translating into an age of $118.93 \mathrm{Ma}(+0.73 /-$ 0.7) (Fig. 3 and Table 1A). This numerical age range corresponds to the early Late Aptian (GST2004).

\section{New ammonoid biostratigraphic data}

\section{Table 1 (LANDSCAPE ORIENTATION - width of page) near here}

In November 2014, an ammonite identified as a Martelites sp. (Fig. 9) was collected by the authors of this study in the lower part of the Xert Formation in Torre Miró $(\mathrm{km} .70$ of the N-232 road; UTM coordinates: $\mathrm{X}=30 \mathrm{~T}$ 747624, $\mathrm{Y}=4508200$ ), in the Morella sub-basin (Fig. 1B). The ammonite was found above the contact between the Morella and Xert formations (Fig. 3). Martelites sp. belongs to the Martelites sarasini Zone (Late Barremian), particularly to the lower part of the Martelites sarasini Subzone of the standard 
Mediterranean zonation found in Reboulet et al. (2014). This finding constitutes the first

459

460

461

462

463

464

465

466

467

468

469

470

471

472

473

474

475

476

477

478

479

480

481

482

quotation of this genus in the Maestrat Basin and allows a precise age calibration of the lower part of the Xert Formation. A Late Barremian age for the lower part of the Xert Formation is in agreement with the strontium-isotopic data presented in this work (samples X1; Fig. 3 and Table 1A).

Figure 9 (width of page) near here

\section{Major transgressive-regressive cycles}

The Barremian-Early Albian sedimentary record of the Maestrat Basin is here subdivided into six long-term transgressive-regressive sequences for comparison with other coeval marine basins (Fig. 3). The hierarchy of the sequences described is considered as high rank, as lower-rank stratigraphic units and surfaces are nested within them. Based on the numerical ages derived from $\mathrm{Sr}$-isotope ratios in Table 1, and the ammonoid biostratigraphic data from the Maestrat Basin tied to the GTS2004 shown in Fig. 3, the duration of the highrank cyclic variations in depositional trends characterized is consistent with the second- (3-50 Ma) and third-order (0.5-3 Ma) relative sea-level cycles of Vail et al. (1991).

The transgressive unit of the first sequence corresponds to the marine limestones and marls of the Artoles Formation (Figs 3, 5A and 6A). The Artoles Formation is a diachronous unit (Salas 1987, Salas et al. 2001). Its base is older in the basin depocentre (Salzedella subbasin; Fig. 1B), where it overlies the Hauterivian platform carbonates of the Llàcova Formation (Salas 1987), and younger in the more marginal settings of the Maestrat Basin (Penyagolosa, Galve, El Perelló and Morella sub-basins; Fig. 1B), where it locally onlaps the continental clastics of the Camarillas Formation (Figs 5A and 6A) or the lacustrine limestones 
and marls of the Cantaperdius Formation (Fig. 3; Salas 1987). The Camarillas and

484 Cantaperdius formations are Barremian in age (e.g., Canérot et al. 1982; Salas 1987; Salas et al. 2001). The regressive strata of the first sequence are represented by the tidal-influenced marine deposits of the upper part of the Artoles Formation (Figs 5A and 6A), the continental clastics of the Morella Formation (Figs 5A-B) and its coastal to marine equivalent, the Cervera del Maestrat Formation (Figs 5C and 6A). The boundary between the transgressive and regressive deposits of Sequence I is located within the Artoles Formation and corresponds to a maximum-flooding surface (Figs 5A and 6A), which lacks numerical dating (Fig. 3), and coincides with the downlap surface of tidal-influenced normal regressive strata above a thick marly unit (Fig. 5A). This first transgressive-regressive sequence is Barremian in age and had a duration of about 3-4 My (Fig. 3).

The onset of the second major transgressive-regressive sequence of relative sea level is marked by a transgressive surface located at the uppermost part of the Morella Formation, where the characteristic continental red clays and sandstones of this formation change into coastal and shallow-marine clastics (Figs 3 and 5A-B). The siliciclastic-influenced deposits of 498 the lower part of the Xert Formation, the limestones with Palorbitolina lenticularis of the 499 upper part of the Xert Formation, and the overlying basinal marls and limestones of the 500 Forcall Formation constitute the rest of the transgressive unit of this second sequence (Figs 5A, 6 and 7A-C). The prograding platform carbonates with rudist bivalves and corals of the

502 Villarroya de los Pinares Formation characterize the regressive strata of the sequence (Figs 6 503 and 7A, C). The maximum-flooding surface of the sequence coincides with the downlap 504 surface exhibited by the normal regressive clinoforms of this latter formation (Bover-Arnal et 505 al. 2009, 2011a, 2014, 2015). This second long-term regressive unit, was terminated by subaerial exposure and local incision of the platform carbonates of the Villarroya de los

507 Pinares Formation (Vennin and Aurell 2001, Bover-Arnal et al. 2009, 2010, 2014, 2015, 
508 Embry et al. 2010). The carbonate platforms of the Villarroya de los Pinares Formation pass

509 basinwards into the marls of the Forcall Formation (Fig. 3; Bover-Arnal et al. 2009, 2010, $5102014,2015)$. This second transgressive-regressive sequence spanned the latest Barremian511 latest Early Aptian time interval and had a duration of around 5 My (Fig. 3). The lower part of the transgressive unit of the third sequence corresponds to peritidal 513 to shallow subtidal deposits back-filling erosional incisions and retrograding platform 514 carbonates belonging to the Villarroya de los Pinares Formation (Bover-Arnal et al. 2009, 515 $2014,2015)$. In the course of this major transgressive event, the platform carbonates of the Villarroya de los Pinares Formation were drowned and buried by marls belonging to the lower 517 part of the Benassal Formation (Figs 3, 6A, 7A, 7C-D and 8B; Bover-Arnal et al. 2009, 2014, 518 2015). The establishment of prograding carbonate platforms with rudists and corals (Benassal 519 Formation), which pass basinwards into marls, marks the regressive stage of the third sequence. These platform carbonates were locally subaerially exposed and incised (Fig. 3; Bover-Arnal et al. 2014). The change in stratal stacking pattern from transgressive marls to normal regressive carbonate platforms is marked by a maximum-flooding surface (Figs 6A, 7A, 7C-D and 8B). This third transgressive-regressive cycle spanned the latest Early Aptian524 early Late Aptian with a duration of $\sim 3$ My (Fig. 3). Transgressive-regressive Sequence IV commences with peritidal to shallow subtidal strata back-filling the erosional incisions formed during the latest regressive stage of the third 527 sequence (Bover-Arnal et al. 2014), and with backstepping of platform carbonates. These 528 carbonate platforms were drowned in the course of the transgression evolving upwards into 529 marly deposits (Figs 3, 6A and 8B; Bover-Arnal et al. 2010). The boundary between the transgressive and normal regressive deposits of the sequence correponds to a maximum531 flooding surface, which is placed at the contact between the underlying marly interval and the 
overlying prograding carbonates, which are rich in orbitolinids, rudists bivalves and corals (Bover-Arnal et al. 2010). The time span of this sequence would be around $4 \mathrm{My}$. The transgressive unit of Sequence V lacks precise age dating (Figs 3, 6A and 87B). However, it is interpreted to be coeval with the occurrence of the ammonoid specimen Acanthohoplites bergeroni in the Galve and Oliete sub-basins (Figs 1B and 3; Weisser 1959, Martínez et al. 1994, Garcia et al. 2014). The regressive unit of the fifh sequence is distinguished by punctuated episodes of carbonate platform development and a progressive change to more coastal and transitional deposits in the uppermost part of the Benassal Formation (Figs 6A and 8B). These regressive strata correspond to intertidal reddish sandstones, sandy limestones and clays, which correspond to the uppermost part of the Benassal Formation (Figs 6A and 8B). Therefore, the time span of sequence $\mathrm{V}$ would be $c$. 2.5 My (Fig. 3).

The subsequent transgressive event (Sequence VI) is marked by the coastal and transitional clastic and coal deposits of the lower part of the Escucha Formation (Figs 3 and 7C). In the Salzedella sub-basin (Fig. 1B), which corresponds to the depocentre of the Maestrat Basin, the lower part of the Escucha Formation contains Albian ammonoids (Moreno-Bedmar et al. 2008, Garcia et al. 2014; Fig. 3). The maximum-flooding zone of this transgressive unit is interpreted to correspond to the stratigraphic position of the Douvilleiceras ammonoids (Fig. 3). Accordingly, this transgressive unit would have spanned around 1.5 My.

Lower-rank changes of relative sea level were superimposed onto the high-rank cycles, reflecting the activity of local tectonics and intra-basinal differences in the rates of sediment input/production and accummulation. In the northern part of the Salzedella subbasin (central Maestrat Basin; Fig. 1B), where the base of the Barremian consists of lacustrine limestones and marls belonging to the Cantaperdius Formation, two lower-rank transgressive- 
regressive sequences equivalent to Sequence I were characterized by Salas (1987). Within the transgressive unit of Sequence II, three conspicuous lower-rank regressive events have been recognized in certain areas of the basin. A higher-frequency regression is recorded at the uppermost part of the Xert Formation in the Galve sub-basin (Fig. 1B; Vennin and Aurell 2001, Bover-Arnal et al. 2010, Embry et al., 2010). The metre-thick and massive beds of limestones with Palorbitolina lenticularis found at the lower-middle part of the Forcall Formation, the so-called 'Barra de Morella' (Canérot et al. 1982, Moreno-Bedmar et al. 2010), also indicate a lower-rank regression of relative sea level within the high-rank transgressive context. The coral-rubble deposits encrusted by Lithocodium aggregatum found in the marls of the Forcall Formation cropping out in the Galve sub-basin (Fig. 1B; Bover-Arnal et al. 2010, 2011b, Schlagintweit et al. 2010, Schlagintweit and Bover-Arnal et al. 2012, 2013), are also consistent with a higher-frequency shallowing of relative sea level.

The three well-developed high-rank transgressive-regressive sequences of the Benassal Formation (sequences III, IV and V) have been recognized only in certain areas of the western part of the Maestrat Basin, in the Penyagolosa and Galve sub-basins (Figs 1B, 6A and 8B; e.g., Martín-Martín et al. 2013). In other areas of the basin, including the northern and eastern parts of the Galve sub-basin (Fig. 1B), only two transgressive-regressive sequences were identified in the Benassal Formation (e.g., Bover-Arnal et al. 2010).

\section{Discussion}

\subsection{Implications for the Barremian-Early Albian chronostratigraphy of the Maestrat Basin}

The numerical ages obtained from the strontium-isotope ratios measured in this study

(Fig. 3 and Table 1), as well as the recent Martelites sp. finding (Fig. 9), result in the re- 
582

583

584

585

586

587

588

589

590

591

592

593

594

595

596

597

598

599

600

601

602

603

604

605

606

evaluation of the chronostratigraphy of the Artoles, Morella, Cervera del Maestrat and Xert formations. The last three lithostratigraphic units, which have been classically interpreted to be of Early Aptian age (e.g., Canérot et al. 1982, Salas 1987, Salas et al. 1995, 2001, Clariana et al. 2000, Vennin and Aurell 2001, Gàmez et al. 2003, Yagüe et al. 2003, Liesa et al. 2006, Canudo et al. 2008a, b, Jorquera-Grau et al. 2009, Bover-Arnal et al. 2009, 2010, MorenoBedmar et al. 2009, 2010, Pérez-García et al. 2009, 2014, Embry et al. 2010, Gasulla et al. 2011a, 2011b, 2012), are here ascribed to the Late Barremian (Figs 2 and 3). However, the ${ }^{87} \mathrm{Sr} /{ }^{86} \mathrm{Sr}$ values of the samples X1 collected at the uppermost part of the Xert Formation give an age of $124.94 \mathrm{Ma}(+0.59 /-0.64)$ (Fig. 3 and Table 1). As the base of the Aptian is at about $125 \mathrm{Ma}$ (GTS2004), an earliest Aptian age for the uppermost part of the Xert Formation cannot be ruled out. Along the same lines, the results sustain a middle/late Early Barremian age for the lower-middle part of the Artoles Formation (samples A1 and A2; Fig. 3 and Table 1), and an early Late Barremian age for its upper part (samples A3), which has been commonly interpreted to be partly Early Aptian in age (e.g., Salas 1987, Salas et al. 1995, 2001, Vennin and Aurell 2001, Caja 2004, Liesa et al. 2006, Embry et al. 2010). The age of the lowermost stratigraphic interval of the Artoles Formation was not investigated in this study. Nevertheless, given that the boundary between the Early and the Late Barremian is dated at about 128.3 Ma (GST2004), the numerical age of 127.49-128.33 Ma obtained from samples A1 and A2 (Fig. 3 and Table 1), which were collected from the lower-middle part of the Artoles Formation, constrains the lower stratigraphic interval of this formation to the Early Barremian. Additionally, the uppermost part of the marls and limestones of La Gaita Formation, which is situated stratigraphically below the Artoles and Llàcova formations in the Salzedella sub-basin (depocentre of the Maestrat Basin; Fig. 1B; Salas et al. 2001), contains latest Hauterivian ammonites belonging to the Pseudothurmannia ohmni Zone (Garcia et al. 2014). 
The basal part of the Forcall Formation lacks an ammonite record or strontium608 stratigraphic constraints (Fig. 3 and Table 1). It could be either terminal Barremian or earliest 609 Aptian. Nevertheless, the base of the first Early Aptian ammonite zone (Deshayesites oglanlensis; Reboulet et al. 2011, 2014) seems to be recorded in the lowermost (but not basal)

611 part of the Forcall Formation (Moreno-Bedmar and Garcia 2011), where specimens of 612 Deshayesites antiquus occur (Fig. 3). The rest of the Forcall Formation is of Early Aptian age 613 (Moreno-Bedmar et al. 2009, 2010, Bover-Arnal et al. 2010, Garcia et al. 2014). In 614 consequence, in the Maestrat Basin, the Barremian-Aptian boundary is located within the stratigraphic interval comprised by the uppermost part of the Xert Formation and the lowermost part of the marls of the Forcall Formation, most likely at the lowermost, non-basal 617 part of this latter lithostratigraphic unit (Fig. 3).

The ages of the Villarroya de los Pinares and Benassal formations are not modified with respect to recent publications (e.g., Bover-Arnal et al. 2012, 2014, 2015, MorenoBedmar et al. 2012, Garcia et al. 2014, Pascual-Cebrian 2014). The Villarroya de los Pinares

621 Formation is confirmed to be Early Aptian in age, whereas the Benassal Formation spans the 622 latest Early Aptian-Late Aptian time interval (Fig. 3 and Table 1). A preliminary 623 biostratigraphic analysis based on orbitolinid foraminifera carried out in the Benassal 624 Formation of the Benicàssim area (Penyagolosa sub-basin; Fig. 1B) suggests that, in this particular locality, the top of this lithostratigraphic unit could be as young as Albian (MartínMartín et al. 2013). However, further study is necessary to confirm these results.

The age of the long-term sea-level falls, which resulted in subaerial exposure and 628 incision of the platform carbonates in the upper part of the Villarroya de los Pinares 629 Formation (Bover-Arnal et al. 2009, 2010, 2011a, 2015) and the lower part of the Benassal 630 Formation (Bover-Arnal et al. 2014) can be also precisely calibrated now. These two major 631 sea-level drops occurred respectively within the Dufrenoyia furcata Zone (late Early Aptian) 
and the upper part of the Epicheloniceras martini Zone (early Late Aptian) (Fig. 3 and Table 1). Based on the numerical ages of the GTS2004, and in accordance with the ammonite occurrences in the basin and the numerical ages derived from ${ }^{87} \mathrm{Sr} /{ }^{86} \mathrm{Sr}$ values measured in samples B1 (Fig. 3 and Table 1), which were collected within the back-filling deposits of the incised valley found in the lower part of the Benassal Formation in the Morella sub-basin (see Bover-Arnal et al. 2014; Figs 1B and 3), the duration of the stratigraphic gaps associated with these subaerial unconformities would be much less than 1 My (Fig. 3). However, the duration of each of these stratigraphic gaps probably varied across the basin.

In this regard, the stratigraphic record can be particularly incomplete in specific parts of the basin due to non-deposition (see Figs 6 and 9 in Salas et al. 2001) or due to ancient and/or present-day erosion. For instance, the Morella Formation is recorded in the central part of the Galve sub-basin (Figs 1B and 5A) but was not deposited in the eastern part of it (Bover-Arnal et al. 2010). The Albian Escucha Formation, as well as Miocene deposits, are locally found above erosional uncoformities affecting the underlying sedimentary record down to the Late Triassic (e.g., Salas 1987, Querol 1990, Solé de Porta et al. 1994, Salas et al. 1995).

The lithologies and fossil distributions represented in Fig. 3 are the most common and significant. Main lateral changes in lithology at the scale of formations occurring throughout the basin are also shown in Fig. 3. For example, the continental part of the Morella Formation (Figs 5A-B) passes laterally (seawards) to its coastal to shallow-marine equivalent, the Cervera del Maestrat Formation (Figs 3 and 5C). The Villarroya de los Pinares Formation is missing in basinal settings due to the lateral transition from platform carbonates to the basinal marls of the Forcall Formation and/or to the marls of the lowermost part of the Benassal Formation (Fig. 3; Bover-Arnal et al. 2009, 2011a, 2014, 2015). The platform carbonates 
656 belonging to the Benassal Formation fade into basinal marls, which are included within the 657 same formation (Fig. 3; Bover-Arnal et al. 2010, 2014).

658 Moreover, the lithostratigraphic units assessed, particularly the Artoles, Forcall and 659 Villarroya de los Pinares formations, are diachronous across the basin. For instance, the 660 Forcall Formation, which records the four Early Aptian ammonoid zones in the Galve and 661 Morella sub-basins, only spans the Deshayesites forbesi Zone in the Oliete sub-basin 662 (Moreno-Bedmar et al. 2010, Garcia et al. 2014). Another case of diachronism is known from 663 the eastern part of the Galve sub-basin (Fig. 1B), where the Villarroya de los Pinares 664 Formation spans part of the Deshayesites deshayesi and Dufrenoyia furcata zones (Bover665 Arnal et al. 2010, 2012), whereas in the central part of this sub-basin, as well as in the Morella 666 sub-basin (Fig. 1B), the Villarroya de los Pinares Formation is latest Early Aptian in age 667 (intra Dufrenoyia furcata Zone) (Bover-Arnal et al. 2010, 2014, 2015). The diachroneity of 668 the Artoles Formation is explained in section 7 of this paper.

670 of the Maestrat Basin is the age of the lowermost part of the Escucha Formation, which has 671 been ascribed either to the Late Aptian (e.g., Boulouard and Canérot 1970, Peyrot et al. 2007, 672 de Gea et al. 2008) or to the Early Albian (e.g., Querol 1990, Querol et al. 1992, Martínez et 673 al. 1994, Solé de Porta and Salas 1994, Solé de Porta et al. 1994, Moreno-Bedmar et al. 674 2008). See also Villanueva-Amadoz et al. (2010) for a review on the different age 675 assignments of the lower part of the Escucha Formation. Besides the fact that the basal part of 676 the Escucha Formation is probably diachronous across the basin (e.g., Canérot et al. 1982), in 677 areas where the base of the Escucha Formation is not marked by an unconformity (Canérot et 678 al. 1982, Salas 1987, Querol 1990, Querol et al. 1992, Salas et al. 1995), the passage from the 679 underlying marine limestones and marls of the Benassal Formation to the marine limestones, 680 marls, sandstones, lutites and coals of the lower part of the Escucha Formation is progressive 
681 and the limit between these two formations is difficult to establish. Thus, the same 682 stratigraphic interval may be arbitrarily ascribed to the uppermost part of the Benassal 683 Formation or to the lowermost part of the Escucha Formation by different authors. This fact 684 probably also accounts for the different age assignments reported for the base of the Escucha 685 Formation in the literature. In this paper, however, the age of the lowermost part of the 686 Escucha Formation is ascribed to the Early Albian following the ammonite findings reported 687 from the depocentre of the Maestrat Basin (Martínez et al. 1994, Moreno-Bedmar et al. 2008), 688 in the Salzedella sub-basin (Fig. 1B) where the Escucha Formation is thus most expanded. Maestrat Basin summarized in Fig. 3 depicts a general pattern, which can be tracked across 691 most of the basin. However, this general chronostratigraphic model may show inherent variations due to local tectono-sedimentary particularities.

693

\subsection{Tethyan significance of the Barremian-Aptian evolution of the Maestrat Basin}

695

The updated chronostratigraphic framework for the Barremian-Early Albian succession from the Maestrat Basin presented herein allows a more precise correlation with coeval sedimentary records from other basins of the Tethys. The Barremian-Aptian boundary in the Maestrat Basin can now be located at around the contact between the Xert and Forcall formations (Fig. 2), most likely in the lowermost, non-basal part of the Forcall Formation

(Figs 2 and 3). The assignment of the basal part of the transgressive marls of the Forcall

702 Formation to the latest Barremian is in agreement with the age of the base of marly transgressive deposits recorded in other basins of the Tethys. 
at the base of a basinal marl-limestone alternation (Delanoy et al. 1997, Ropolo et al. 1999,

707 2000), which overlies the Urgonian carbonates of the Provence Platform. The top of these 708 limestones of the Provence Platform at Cassis-La Bédoule is marked by a drowning 709 discontinuity (Masse and Fenerci-Masse 2011). This scenario is comparable to that described 710 in the Maestrat Basin where the Late Barremian platform carbonates of the Xert Formation 711 were drowned in the terminal Barremian and overlain by the basinal marls of the Forcall

712 Formation (Fig. 3). Similarly, in Cassis-La Bédoule, the Barremian-Aptian boundary is also 713 located in the lower, non-basal part of the transgressive basinal marly-limestone unit

714 (Delanoy et al. 1997, Ropolo et al. 1999, 2000).

Other examples are found in the Basque-Cantabrian Basin ( $\mathrm{N}$ Spain), where 716 continental deposits of the Wealden series are overlain by marine marls of the Errenaga 717 Formation. García-Mondéjar et al. (2009) report the presence of the ammonite Valdedorsella sp. at the base of this transgressive marly unit, and ascribe this genus to the latest Barremian.

719 Along the same lines, in the Organyà Basin (S Pyrenees), the base of the basinal marls of the Cabó Formation is characterized by an ammonite record that includes Pseudocrioceras 721 waagenoides and Acrioceras sp., and thus belongs to the Pseudocrioceras waagenoides Sub722 zone of the Imerites giraudi Zone (Late Barremian) (Moreno-Bedmar 2010, Moreno-Bedmar and Garcia 2011). Below the marly transgressive deposits of the Cabó Formation, Valanginian to Barremian platform carbonates belonging to the Prada Formation are found (Bernaus et al. 2002, 2003).

Therefore, in the Maestrat Basin, the passage from the Barremian into the Aptian occurred in the course of a wide transgression, which started in the Late Barremian and ended within the Early Aptian. This Late Barremian-Early Aptian major transgressive event (Sequence II) drowned the carbonate systems corresponding to the Xert Formation (Fig. 3), as well as coeval carbonate platforms from nearby basins (e.g., Masse and Fenerci-Masse 2011), 
within the terminal Barremian. In addition, according to the GTS2004, the Late BarremianEarly Aptian marine transgression lasted between 3 and 4 My (Fig. 3) and thus would be in agreement with a second-order (sensu Vail et al., 1991) eustatic event. The acme of this major transgression occurred within the Early Aptian (Fig. 3; e.g., Bover-Arnal et al. 2010). As a matter of fact, transgressive deposits of Early Aptian age are widespread along the margins of the Tethys ocean (e.g., Föllmi et al. 1994, Sahagian et al. 1996, Hardenbol et al. 1998, Wissler et al. 2003, Husinec and Jelaska 2006, Hfaiedh et al. 2013, Suarez-Gonzalez et al. 2013, Pictet et al. 2015).

Sample F1 corresponds to a shell of a polyconitid rudist collected at the lower part of the Forcall Formation in the Galve sub-basin within a coral rubble horizon encrusted by Lithocodium aggregatum (Schlagintweit et al. 2010, Bover-Arnal et al. 2011b). This coral rubble level is coeval with the OAE1 (Moreno-Bedmar et al. 2009, Bover-Arnal et al. 2010); more exactly with the global positive $\mathrm{C}$-isotope excursion characterized as the segment $\mathrm{C} 4$ by Menegatti et al. (1998) (see Cors et al. 2015). The ${ }^{87} \mathrm{Sr} /{ }^{86} \mathrm{Sr}$ ratio obtained from this sample translates into a numerical age of $123.6 \mathrm{Ma}(+0.53 /-0.57)$ (Fig. 3 and Table 1). This gives a rough age of the positive excursion of the carbon-isotope values correlatable with the segment C4 of Menegatti et al. (1998), and of the OAE1a itself in this basin.

On the other hand, the location of the Barremian-Aptian boundary within the stratigraphic interval spanning the lowermost section of the Forcall Formation ascribes the first Palorbitolina lenticularis occurrences recorded at the upper part of the Xert Formation (e.g., Salas 1987, Vennin and Aurell 2001, Bover-Arnal et al. 2010, Embry et al. 2010) to the Late Barremian (Fig. 3), and not the Early Aptian as previously thought (Fig. 2). In this respect, the Late Barremian age of the oldest Palorbitolina lenticularis blooms found in the Maestrat basin is consistent with other first occurrences identified in other Tethyan regions such as the Arabian Plate (e.g., Schroeder et al. 2010), the Pyrenees (e.g., Bernaus et al. 2002, 
2003), the Helvetic Nappes (e.g., Stein et al. 2012), the Provence Platform in SE France (e.g.,

757 Leonide et al. 2012) or the French Subalpine Chains (e.g., Huck et al. 2013). Furthermore,

Palorbitolina lenticularis mass-occurrences are also recorded within the Early Aptian Forcall

Formation in the Maestrat Basin (e.g., Schroeder 1964, Canérot et al. 1982, Bover-Arnal et al. 2010, 2011b, 2014), as well as in other Early Aptian deposits of the Tethys and the Atlantic extension of it (e.g., Arnaud and Arnaud-Vanneau 1991, Vilas et al. 1995, Husinec et al. 2000, Burla et al. 2008, Schroeder et al. 2010, Leonide et al. 2012). Albian succession of the Maestrat Basin are next compared to the sequences compiled by Hardenbol et al. (1998) from the European basins of the Tethys (Fig. 3). These sequences of Hardenbol et al. (1998) were tied to numerical ages by Gradstein et al. (2004), as done in the present study with the interpreted major Barremian-Early Albian transgressive-regressive sequences. Sequence I (Figs 5A and 6A) comprises the Barr1, Barr2, Barr3, Barr4 and Barr5 sequences of Hardenbol et al. (1998) and thus, there is not a fit between them (Fig. 3).

770 Sequence II (Figs 3, 5A-B, 6 and 7A, C) comprises the sequences Barr6, Ap1, Ap2 and Ap3 771 of Hardenbol et al. (1998). The acme of the transgression related to Sequence II occurred 772 around the boundary between the Deshayesites forbesi and Deshayesites deshayesi zones 773 (Fig. 3) as also marked by Gradstein et al. (2004). The regression of Sequence II spans most 774 of the Deshayesites deshayesi and Dufrenoyia furcata zones (Fig. 3), also throughout the 775 Tethys (Gradstein et al. 2004). Sequence III (Figs 3, 6A, 7A, D and 8B) fits rather well with 776 the sequence Ap4 of Hardenbol et al. (1998). The start of the transgression of Sequence IV 777 (Figs 3, 6A and 8B) is rather coeval with the transgression of sequence Ap5 (Gradstein et al., 778 2004). However, the regression of Sequence IV (Figs 3, 6A and 8B) is not correlatable with 779 the regressive part of the sequence Ap5 of Hardenbol et al. (1998). The transgressive part of 780 Sequence $\mathrm{V}$ is coeval with the acme of the transgression corresponding to the sequence Ap5 
of Hardenbol et al. (1998) (Fig. 3). The start of the regression of Sequence V is correlatable to

782 the regression of sequence Ap5 (Fig. 3). On the other hand, global sequences Ap6, Al1 and

$783 \mathrm{~A} 12$ do not show any pattern comparable to the major transgressive-regressive sequences

784 characterized in the Maestrat Basin (Fig. 3). However, the onset of transgression during

785 Sequence VI is correlatable with the upper part of the transgression of sequence Ap6 (Fig. 3).

786 Accordingly, sequences II and III (Figs 3, 5A-B, 6, 7A, 7C-D and 8B), as well as the

787 transgressive parts of sequences IV and V, the start of the regression of Sequence V, and the 788 onset of transgression of Sequence VI (Figs 3, 6A and 8B), seem to have responded to a 789 eustatic signal of Tethyan significance.

790

\section{Conclusions}

792

According to the numerical ages derived from strontium-isotope data and the new ammonoid finding presented in this study, the Aptian Stage in the Maestrat Basin began within the stratigraphic interval comprised between the uppermost part of the Xert Formation and the lowermost part of the Forcall Formation. In this study, by analogy with the ammonoid-calibrated latest Barremian age of the basal part of the transgressive marl successions recorded in the nearby Vocontian, Organyà and Basque-Cantabrian basins, the stratigraphic location of the Barremian-Aptian boundary within the lowermost, non-basal part of the marly transgressive deposits of the Forcall Formation is favoured.

The new chronostratigraphic considerations presented in this paper indicate that: i) the

802 dinosaur and other vertebrate remains of the Morella Formation and the lowermost part of the Xert Formation are of Late Barremian age, ii) the first Palorbitolina lenticularis blooms 
806 proliferation of Palorbitolina lenticularis along the margins of the Tethys, iv) this

807 transgressive event started in the latest Barremian and drowned terminal Barremian carbonate 808 platforms (Xert Formation) throughout the basin, v) extensive carbonate platforms recovered 809 coevally with a post-OAE1a late Early Aptian major regression of relative sea level, spanning 810 the upper part of the Deshayesites deshayesi Zone and most of the Dufrenoyia furcata Zone, 811 vi) these carbonate platforms, which belong to the rudist- and coral-bearing Villarroya de los 812 Pinares Formation, terminated with subaerial exposure or drowning within the uppermost 813 Dufrenoyia furcata Zone (latest Early Aptian), vii) a second episode of rudist- and coral814 dominated carbonate platform development occurred in the upper part of the Epicheloniceras 815 martini Zone (early Late Aptian), viii) these carbonate platforms correspond to the Benassal 816 Formation and were terminated due to emersion or drowning within the time interval 817 spanning the uppermost part of the Epicheloniceras martini Zone and the lowermost part of 818 the Parahoplites melchioris Zone (early Late Aptian), and ix) punctuated and minor episodes 819 of carbonate platform growth occurred during the latest Aptian, gradually evolving into more 820 coastal and transitional deposits in the uppermost part of the Benassal Formation, which is 821 overlain by Early Albian clastic and coal deposits corresponding to the Escucha Formation.

\section{Acknowledgements}

We are especially grateful to André Strasser, Peter W. Skelton and to an anonymous 826 reviewer for their helpful comments and suggestions on the manuscript. Jordi Illa and 827 Alejandro Gallardo are greatly thanked for laboratory assistance. We are grateful to José 828 Miguel Gasulla for inviting us to visit a quarry pit where the Morella Formation is mined and 829 allowing us to take the picture shown in Fig. 5B. Prof. Juan Diego Martín-Martín kindly 830 provided the panoramic photo of the Orpesa Range shown in Fig. 8A. This study was 
831 financed by the I+D+i research project CGL2008-04916, the Consolider-Ingenio 2010

832 programme, under CSD 2006-0004 "Topo-Iberia", and the Grup de Recerca Reconegut per la 833 Generalitat de Catalunya 2014 SGR 251 "Geologia Sedimentària".

834

\section{References}

836

837 Aguilar, M.J., Ramírez del Pozo, J., Riba, O., 1971. Algunas precisiones sobre la 838 sedimentación y paleoecología del Cretácico inferior en la Zona de Utrillas-Villarroya de los

839 Pinares (Teruel). Estudios Geológicos 27, 497-512.

840

841 Al-Aasm, I.S., Veizer, J., 1986. Diagenetic stabilization of aragonite and low-Mg calcite. I.

842 Trace elements in rudists. Journal of Sedimentary Petrology 56, 763-770.

843

844 Arnaud, H., Arnaud-Vanneau, A., 1991. Les calcaires Urgoniens des massifs subalpins

845 septentrionaux et du Jura (France): âge et discussion des données stratigraphiques. Géologie

846 Alpine 67, 63-79.

847

848 Banner, J.L., 1995. Application of the trace element and isotope geochemistry of strontium to 849 studies of carbonate diagenesis. Sedimentology 42, 805-824.

850

851 Bachmann, M., Hirsch, F., 2006. Lower Cretaceous carbonate platform of the eastern Levant 852 (Galilee and the Golan Heights): stratigraphy and second-order sea-level change. Cretaceous 853 Research 27, 487-512.

854

855 Bernaus, J.M., Arnaud-Vanneau, A., Caus, E., 2002. Stratigraphic distribution of 
856 Valanginian-Early Aptian shallow-water benthic foraminifera and algae, and depositional

857 sequences of a carbonate platform in a tectonically-controlled basin: the Organyà Basin,

858 Pyrenees, Spain. Cretaceous Research 23, 25-36.

859

860 Bernaus, J.M., Arnaud-Vanneau, A., Caus, E., 2003. Carbonate platform sequence

861 stratigraphy in a rapidly subsiding area: the Late Barremian-Early Aptian of the Organyà

862 basin, Spanish Pyrenees. Sedimentary Geology 159, 177-201.

863

864 Bodin, S., Fiet, N., Godet, A., Matera, V., Westermann, S., Clément, A., Janssen, N.M.M.,

865 Stille, P., Föllmi, K.B., 2009. Early Cretaceous (late Berriasian to early Aptian)

866 palaeoceanographic change along the northwestern Tethyan margin (Vocontian Trough,

867 southeastern France): $\delta^{13} \mathrm{C}, \delta^{18} \mathrm{O}$ and $\mathrm{Sr}$-isotope belemnite and whole-rock records.

868 Cretaceous Research 30, 1247-1262.

869

870 Boix, C., Frijia, G., Vicedo, V., Bernaus, J.M., Di Lucia, M., Parente, M., Caus, E., 2011.

871 Larger foraminifera distribution and strontium isotope stratigraphy of the La Cova limestones

872 (Coniacian-Santonian, "Serra del Montsec", Pyrenees, NE Spain). Cretaceous Research 32,

$873 \quad 806-822$.

874

875 Bonilla-Rodríguez, A.J., González, L.A., Douglas Walker, J., Santos, H., 2014. Strontium

876 isotope $\left({ }^{87} \mathrm{Sr} /{ }^{86} \mathrm{Sr}\right)$ stratigraphy from the Coalcomana-Caprinuloidea rudist assemblage in the

877 Greater Antilles (Puerto Rico, Dominican Republic and Jamaica). Cretaceous Research 50,

$87897-109$.

879 
880 Bover-Arnal, T., Salas, R., Moreno-Bedmar, J.A., Bitzer, K., 2009. Sequence stratigraphy and 881 architecture of a late Early-Middle Aptian carbonate platform succession from the western 882 Maestrat Basin (Iberian Chain, Spain). Sedimentary Geology 219, 280-301.

883

884 Bover-Arnal, T., Moreno-Bedmar, J.A., Salas, R., Skelton, P.W., Bitzer, K., Gili, E., 2010.

885 Sedimentary evolution of an Aptian syn-rift carbonate system (Maestrat Basin, E Spain): 886 effects of accommodation and environmental change. Geologica Acta 8, 249-280.

887

888 Bover-Arnal, T., Salas, R., Skelton, P.W., Gili, E., Moreno-Bedmar, J.A., 2011a. The Aptian 889 carbonate platforms of the western Maestrat Basin: a textbook example of four systems tract890 based sequence stratigraphy. In: Arenas, C., Pomar, L., Colombo, F. (Eds.), Pre-Meeting 891 Field trips Guidebook, 28th IAS Meeting, Zaragoza. Sociedad Geológica de España, Geo892 Guías 7, 27-64.

893

894 Bover-Arnal, T., Salas, R., Martín-Closas, C., Schlagintweit, F., Moreno-Bedmar, J.A., 2011 b. 895 Expression of an oceanic anoxic event in a neritic setting: Lower Aptian coral rubble deposits 896 from the western Maestrat Basin (Iberian Chain, Spain). Palaios 26, 18-32.

897

Bover-Arnal, T., Löser, H., Moreno-Bedmar, J.A., Salas, R., Strasser, A., 2012. Corals on the slope (Aptian, Maestrat Basin, Spain). Cretaceous Research 37, 43-64.

900

901 Bover-Arnal, T., Salas, R., Guimerà, J., Moreno-Bedmar, J.A., 2014. Deep incision on an 902 Aptian carbonate succession indicates major sea-level fall in the Cretaceous. Sedimentology 903 61, 1558-1593. 
905 Bover-Arnal, T., Pascual-Cebrian, E., Skelton, P.W., Gili, E., Salas, R., 2015. Patterns in the 906 distribution of Aptian rudists and corals within a sequence-stratigraphic framework (Maestrat 907 Basin, E Spain). Sedimentary Geology 321, 86-104.

908

909 Boulouard, C., Canérot, J., 1970. Données nouvelles sur l'Aptien supérieur et l'Albien dans le 910 Bas-Aragón et le Maestrazgo (Espagne). Bulletin du Centre de Recherches Pau-SNPA 4, $911 \quad 453-463$.

912

913 Brand, U., Veizer, J., 1980. Chemical diagenesis of a multicomponent carbonate system: 1.

914 Trace elements. Journal of Sedimentary Petrology 50, 1219-1236.

915

916 Brand, U., Jiang, G., Azmy, K., Bishop, J., Montanez, I.P., 2012. Diagenetic evaluation of a 917 Pennsylvanian carbonate succession (Bird Spring Formation, Arrow Canyon, Nevada, U.S.A) $918-1$ :Brachiopod and whole rock comparison. Chemical Geology 308, 26-39.

919

920 Brand, U., Logan, A., Bitner, M.A., Griesshaber, E., Azmy, K., Buhl, D., 2011. What is the 921 ideal proxy of Paleozoic seawater chemistry? Memoirs of the Association of Australasian 922 Palaeontologists 41, 9-24.

923

924 Burla, S., Heimhofer, U., Hochuli, P.A., Weissert, H., Skelton, P., 2008. Changes in sedimentary 925 patterns of coastal and deep-sea successions from the North Atlantic (Portugal) linked to Early 926 Cretaceous environmental change: Palaeogeography, Palaeoclimatology, Palaeoecology 257, $927 \quad 38-57$. 
Burla, S., Oberli, F., Heimhofer, U., Wiechert, U., Weissert, H., 2009. Improved time control

930 on Cretaceous coastal deposits: new results from $\mathrm{Sr}$ isotope measurements using laser 931 ablation. Terra Nova 21, 401-409.

932

933 Caja, M.A., 2004. Procedencia y diagénesis de los sedimentos del Jurásico superior-Cretácico 934 inferior (Facies Weald) en las subcuencas occidentales de la Cuenca del Maestrazgo, 935 Cordillera Ibérica oriental. PhD thesis. Universidad Complutense de Madrid. 293 p.

936

937

Canérot, J., Cugny, P., Pardo, G., Salas, R., Villena, J., 1982. Ibérica Central-Maestrazgo. In: 938 García, A. (Ed.), El Cretácico de España. Universidad Complutense de Madrid, 273-344.

940 Canudo, J.I., Royo-Torres, R., Cuenca-Bescós, G., 2008a. A new sauropod: Tastavinsaurus 941 sanzi gen. et sp. nov. from the Early Cretaceous (Aptian) of Spain. Journal of Vertebrate 942 Paleontology 28, 712-731.

943

944 Canudo, J.I., Gasulla, J.M., Gómez-Fernández, D., Ortega, F., Sanz, J.L., Yagüe, P., $2008 b$. 945 Primera evidencia de dientes aislados atribuidos a Spinosauridae (Theropoda) en el Aptiano 946 inferior (Cretácico Inferior) de Europa: Formación Arcillas de Morella (España). 947 Ameghiniana (Rev. Asoc. Paleontol. Argent.) 45, 649-662.

949 Catuneanu, O., Abreu, V., Bhattacharya, J.P., Blum, M.D., Dalrymple, R.W., Eriksson, P.G., 950 Fielding, C.R., Fisher, W.L., Galloway, W.E., Gibling, M.R., Giles, K.A., Holbrook, J.M., 951 Jordan, R., Kendall, C.G.St.C., Macurda, B., Martinsen, O.J., Miall, A.D., Neal, J.E., 952 Nummedal, D., Pomar, L., Posamentier, H.W., Pratt, B.R., Sarg, J.F., Shanley, K.W., Steel, 
R.J., Strasser, A., Tucker, M.E., Winker, C., 2009. Towards the standardization of sequence

954 stratigraphy. Earth-Science Reviews 92, 1-33.

955

956 Catuneanu, O., Galloway, W.E., Kendall, C.G.St.C., Miall, A.D., Posamentier, H.W.,

957 Strasser, A., Tucker, M.E., 2011. Sequence stratigraphy: methodology and nomenclature.

958 Newsletters on Stratigraphy 44, 173-245.

959

960 Clariana, M.P.,1999. Estratigrafía y sedimentología de las Facies Urgon (Aptiense) en la

961 Subcuenca de Las Parras (Provincia de Teruel). PhD thesis. Universidad de Zaragoza, 132 p.

962

963 Clariana, M. P., Meléndez, A., Soria, A. R., 2000. Los depósitos terrígenos de la base de la 964 secuencia de depósito Aptiense superior. Subcuenca de las Parras (provincia de Teruel). 965 Geogaceta 27, 43-45.

966

967 Cors, J., Heimhofer, U., Adatte, T., Hochuli, P.A., Huck, S., Bover-Arnal, T., 2015. Spore968 pollen assemblages show delayed terrestrial cooling in the aftermath of OAE 1a. Geological 969 Magazine 152, 632-647.

970

971 de Gea, G.A., Rodríguez-López, J.P., Meléndez, N., Soria, A.R., 2008. Bioestratigrafía de la 972 Fm. Escucha a partir del estudio de foraminíferos planctónicos y nanofósiles en el sector de 973 Alcaine, Teruel. Geogaceta 44, 115-118.

974

975 Delanoy, G., Busnardo, R., Ropolo, P., Gonnet, R., Conte, G., Moullade, M., Masse, J.P., 976 1997. The "Pseudocrioceras beds" at La Bédoule (SE France) and the position of the 
977 Barremian-Aptian boundary in the historical lower Aptian stratotype. Compte Rendu de

978 l'Académie des Sciences de Paris, Sciences de la Terre et des planètes 325, 593-599.

979

980 Embry, J.-C., Vennin, E., Van Buchem, F. S. P., Schroeder, R., Pierre, C., Aurell, M., 2010.

981 Sequence stratigraphy and carbon isotope stratigraphy of an Aptian mixed carbonate982 siliciclastic platform to basin transition (Galve sub-basin, NE Spain). In: Van Buchem, F. S. 983 P., Gerdes, K. D., Esteban, M. (Eds.), Mesozoic and Cenozoic Carbonate Systems of the 984 Mediterranean and the Middle East: Stratigraphic and Diagenetic Reference Models. 985 Geological Society Special Publications, London 329, 113-143.

986

987 Föllmi, K.B., Weissert, H., Bisping, M., Funk, H., 1994. Phosphogenesis, carbon-isotope 988 stratigraphy, and carbonate-platform evolution along the Lower Cretaceous northern Tethyan 989 margin. Geological Society of America Bulletin 106, 729-746.

990

991 Frijia, G., Parente, M., 2008. Strontium isotope stratigraphy in the upper Cenomanian 992 shallow-water carbonates of the southern Apennines: short-term perturbations of marine $993{ }^{87} \mathrm{Sr} /{ }^{86} \mathrm{Sr}$ during the oceanic anoxic event 2. Palaeogeography, Palaeoclimatology, 994 Palaeoecology 261, 15-29.

995

996 Frijia, G., Parente, M., Di Lucia, M., Mutti, M., 2015. Carbon and strontium isotope 997 stratigraphy of the Upper Cretaceous (Cenomanian-Campanian) shallow-water carbonates of 998 southern Italy: Chronostratigraphic calibration of larger foraminifera biostratigraphy.

999 Cretaceous Research 53, 110-139. 
1001 Gàmez, D., Paciotti, P., Colombo, F., Salas, R., 2003. La Formación Arcillas de Morella

1002 (Aptiense inferior), Cadena Ibérica oriental (España): caracterización sedimentológica.

1003 Geogaceta 34, 191-194.

1004

1005 Garcia, R., Moreno-Bedmar, J.A., Bover-Arnal, T., Company, M., Salas, R., Latil, J.L.,

1006 Martín-Martín, J.D., Gomez-Rivas, E., Bulot, L.G., Delanoy, G., Martínez, R., Grauges, A., 1007 2014. Lower Cretaceous (Hauterivian-Albian) ammonite biostratigraphy in the Maestrat 1008 Basin (E Spain). Journal of Iberian Geology 40, 99-112.

1009

1010 García-Mondéjar, J., Owen, H.G., Raisossadat, N., Millán, M.I., Fernández-Mendiola, P.A., 1011 2009. The Early Aptian of Aralar (northern Spain): stratigraphy, sedimentology, ammonite 1012 biozonation, and OAE1. Cretaceous Research 30, 434-464.

1013

1014 Gasulla, J.M., Ortega, F., Escaso, F., Pérez-García, A., 2011a. Los yacimientos de vertebrados 1015 de la Formación Arcillas de Morella (Aptiense inferior). In: Pérez-García, A., Gascó, F., 1016 Gasulla, J.M., Escaso, F. (Eds.), Viajando a Mundos Pretéritos. Ayuntamiento de Morella, 1017 Morella, Castellón, 157-172.

1018

1019 Gasulla, J.M., Ortega, F., Pereda-Suberbiola, X., Escaso, F., Sanz, J.L., 2011b. Elementos de 1020 la armadura dérmica del dinosaurio anquilosaurio Polacanthus Owen, 1865, en el Cretácico 1021 Inferior de Morella (Castellón, España). Ameghiniana 48, 508-519.

1022

1023 Gasulla, J.M., Ortega, F., Sanz, J.L., Escaso, F., Yagüe, P., Pérez-García, A., 2012. Els 1024 vertebrats de la Formació Argiles de Morella (Aptià inferior, Cretaci Inferior). Nemus 2, 151025 27. 
1027 Gomez-Rivas, E., Corbella, M., Martín-Martín, J.D., Stafford, S.L., Teixell, A., Bons, P.D., 1028 Griera, A., Cardellach, E., 2014. Reactivity of dolomitizing fluids and Mg source evaluation 1029 of fault-controlled dolomitization at the Benicàssim outcrop analogue (Maestrat Basin, 1030 Spain). Marine and Petroleum Geology 55, 26-42.

1031

1032 Gradstein, F.M., Ogg, J.G., Smith, A.G., 2004. A Geologic Time Scale 2004. Cambridge 1033 University Press, Cambridge, 610 p.

1034

1035 Hardenbol, J., Thierry, J., Farley, M.B., Jacquin, T., Graciansky, de P.-C., Vail, P.R., 1998.

1036 Mesozoic and Cenozoic sequence chronostratigraphic framework of European basins. In:

1037 Graciansky, de P.-C., Hardenbol, J., Jacquin, T., Vail, P.R. (Eds.), Mesozoic and Cenozoic 1038 sequence stratigraphy of European basins, SEPM Special Publication 60, 3-13.

1039

1040 Hfaiedh, R., Arnaud Vanneau, A., Godet, A., Arnaud, H., Zghal, I., Ouali, J., Latil, J.-L., 1041 Jallali, H., 2013. Biostratigraphy and palaeoenvironmental evolution of the Aptian succession 1042 at Jebel Bir Oum Ali (Northern Chain of Chotts, South Tunisia). Cretaceous Research 46, $1043 \quad 177-207$.

1044

1045 Huck, S., Heimhofer, U., Rameil, N., Bodin, S., Immenhauser, A., 2011. Strontium and 1046 carbon-isotope chronostratigraphy of Barremian-Aptian shoal-water carbonates: Northern 1047 Tethyan platform drowning predates OAE 1a. Earth and Planetary Science Letters 304, 5471048558. 
1050 Huck, S., Heimhofer, U., Immenhauser, A., Weissert, H., 2013. Carbon-isotope stratigraphy

1051 of Early Cretaceous (Urgonian) shoal-water deposits: Diachronous changes in carbonate-

1052 platform production in the north-western Tethys. Sedimentary Geology 290, 157-174.

1053

1054 Husinec, A., Velic, I., Fucek, L., Vlahovic, I., Maticec, D., Ostric, N., Korbar, T., 2000. Mid

1055 Cretaceous orbitolinid (Foraminiferida) record from the islands of Cres and Losinj (Croatia)

1056 and its regional stratigraphic correlation. Cretaceous Research 21, 155-171.

1057

1058 Husinec, A., Jelaska, V., 2006. Relative sea-level changes recorded on an isolated carbonate

1059 platform: Tithonian to Cenomanian succession, Southern Croatia. Journal of Sedimentary

1060 Research 76, 1120-1136.

1061

1062 Jaramillo-Vogel, D., Strasser, A., Frijia, G., Spezzaferri, S., 2013. Neritic isotope and

1063 sedimentary records of the Eocene-Oligocene greenhouse-icehouse transition: The Calcare di

1064 Nago Formation (northern Italy) in a global context. Palaeogeography, Palaeoclimatology,

1065 Palaeoecology 369, 361-376.

1066

1067 Jorquera-Grau, A., Santos-Cubedo, A., de Santisteban Bové, C., Galobart Lorente, A., 2009.

1068 Plesiosaurs (Reptilia: Sauropterygia) from the Arcillas de Morella Formation (Aptian, Lower

1069 Cretaceous) of Castellón (Spain). Paleolusitana 1, 229-235.

1070

1071 Leonide, P., Borgomano, J., Masse, J-P., Doublet, S., 2012. Relation between stratigraphic 1072 architecture and multi-scale heterogeneities in carbonate platforms: The Barremian-lower 1073 Aptian of the Monts de Vaucluse, SE France. Sedimentary Geology 265, 87-109. 
1075 López Llorens, J., 2007. Hallazgo de Imerites giraudi giraudi, ammonítido barremiense, en 1076 las “Arcillas de Morella”. Consecuencias. Batalleria 13, 53-56.

1077

1078 Marin, P., Sornay, J., 1971. Précisions sur l'âge des formations aptiennes aux confins de 1079 l'Aragón et du Maestrazgo (Provinces de Teruel et Castellón de la Plana, Espagne). Comptes 1080 Rendus sommaires de la Société géologique de France 3, 165-167.

1081

1082 Martín-Martín, J.D., Gomez-Rivas, E., Bover-Arnal, T., Travé, A., Salas, R., Moreno1083 Bedmar, J.A., Tomás, S., Corbella, M., Teixell, A., Vergés, J., Stafford, S.L., 2013. The 1084 Upper Aptian to Lower Albian synrift carbonate succession of the southern Maestrat Basin 1085 (Spain): Facies architecture and fault-controlled stratabound dolostones. Cretaceous Research $1086 \quad 41,217-236$.

1087

Martín-Martín, J.D., Travé, A., Gomez-Rivas, E., Salas, R., Sizun, J.-P., Vergés, J., Corbella, M., Stafford, S.L., Alfonso, P., 2015. Fault-controlled and stratabound dolostones in the Late 1090 Aptian-earliest Albian Benassal Formation (Maestrat Basin; E Spain): Petrology and 1091 geochemistry constraints. Marine and Petroleum Geology 66, 83-102.

1092

1093 Martínez, R., Grauges, A., Salas, R., 1994. Distribución de los ammonites del Cretácico 1094 inferior de la Cordillera Costera Catalana e Ibérica Oriental. Cuadernos de Geología Ibérica $1095 \quad \mathbf{1 8}, 337-354$.

1097 Masse, J.-P., Fenerci-Masse, M., 2011. Drowning discontinuities and stratigraphic correlation 1098 in platform carbonates. The late Barremian-early Aptian record of southeast France.

1099 Cretaceous Research 32, 659-684. 
1101 McArthur, J.M., Howarth, R.J., 2004. Strontium isotope stratigraphy. In: Gradstein, F., Ogg,

1102 J., Smith, A. (Eds.), A Geological Time Scale. Cambridge University Press, Cambridge, U.K, 1103 96-105.

1104

1105 McArthur, J.M., Howarth, R.J., Bailey, T.R., 2001. Strontium isotope stratigraphy: lowess

1106 version 3. Best-fit to the marine Sr-isotope curve for 0 to $509 \mathrm{Ma}$ and accompanying look-up

1107 table for deriving numerical age. Journal of Geology 109, 155-170.

1108

1109 McArthur, J.M., Howarth, R.J., Shields, G.A., 2012. Strontium isotope stratigraphy. In:

1110 Gradstein, F.M., Ogg, J.G., Schmitz, M., Ogg, G. (Eds.), The Geologic Time Scale 2012.

1111 Elsevier Science Limited. 1144 p.

1112

1113 McArthur, J.M., 1994. Recent trends in strontium isotope stratigraphy. Terra Nova 6, 3311114358.

1115

1116 McArthur, J.M., Rio, D., Massari, F., Castratori, D., Bailey, T.R., Thirlwall, M., Houghton,

1117 S., 2006. A revised Pliocene record formarine ${ }^{87} \mathrm{Sr} /{ }^{86} \mathrm{Sr}$ used to date an interglacial event

1118 recorded in the Cockburn Island Formation, Antarctic Peninsula. Palaeogeography,

1119 Palaeoclimatology, Palaeoecology 242, 126-136.

1120

1121 Menegatti, A.P., Weissert, H., Brown, R.S., Tyson, R.V., Farrimond, P., Strasser, A., Caron,

1122 M., 1998. High-resolution $\delta^{13} \mathrm{C}$ stratigraphy through the early Aptian "Livello Selli" of the

1123 Alpine Tethys. Paleoceanography 13, 530-545. 
1125 Moreno-Bedmar, J.A., Company, M., Bover-Arnal, T., Salas, R., Delanoy, G., Martínez, R.,

1126 Grauges, A., 2009a. Biostratigraphic characterization by means of ammonoids of the lower

1127 Aptian Oceanic Anoxic Event (OAE1a) in the eastern Iberian Chain (Maestrat Basin, eastern

1128 Spain). Cretaceous Research 30, 864-872.

1129

1130 Moreno-Bedmar, J.A., Company, M., Bover-Arnal, T., Salas, R., Maurrasse, F.J., Delanoy,

1131 G., Grauges, A., Martínez, R., 2010a. Lower Aptian ammonite biostratigraphy in the Maestrat

1132 Basin (Eastern Iberian Chain, Eastern Spain). A Tethyan transgressive record enhanced by

1133 synrift subsidence. Geologica Acta 8, 281-299.

1134

1135 Moreno-Bedmar, J.A., Bover-Arnal, T., Barragán, R., Salas, R., 2012. Uppermost Lower

1136 Aptian transgressive records in Mexico and Spain: chronostratigraphic implications for the

1137 Tethyan sequences. Terra Nova 24, 333-338.

1138

1139 Moreno-Bedmar, J.A., Bulot, L., Latil, J.L., Martínez, R., Ferrer, O., Bover-Arnal, T., Salas,

1140 R., 2008. Precisiones sobre la edad de la base de la Fm. Escucha, mediante ammonoideos, en

1141 la subcuenca de la Salzedella, Cuenca del Maestrat (E Cordillera Ibérica). Geo-Temas 10,

$1142 \quad 1269-1272$.

1143

1144 Moreno-Bedmar, J.A., Company, M., Barragán, R., Salas, R., Martín- Martín, J.D., Bover-

1145 Arnal, T., Gomez-Rivas, E., 2009b. Precisiones, mediante ammonoideos, sobre la edad de la

1146 Fm. Benassal, Cuenca del Maestrat (Cadena Ibérica). In: Palmqvist, P., Pérez-Claros, J.A.

1147 (Coords.), XXV Jornadas de la Sociedad Española de Paleontología. Libro de Resúmenes.

1148 Universidad de Málaga, 231-234.

1149 
1150 Moreno-Bedmar, J.A., 2010. Ammonits de l’Aptià inferior de la península Ibèrica.

1151 Biostratigrafia i aportacions a l'estudi del Oceanic Anoxic Event 1a. PhD thesis, Universitat

1152 de Barcelona, Barcelona, 331 p.

1153

1154 Moreno-Bedmar, J.A., Garcia, R., Salas, R., Ferrer, O., 2010b. Bioestratigrafía de los

1155 ammonites del Aptiense inferior (Cretácico Inferior) del Perelló (Tarragona). In: Moreno-

1156 Azanza, M., Díaz-Martínez, I., Gasca, J.M., Melero-Rubio, M., Rabal-Garcés, R., Sauqué, V.

1157 (Eds.). VIII Encuentro de Jóvenes Investigadores en Paleontología, volumen de actas, Cidaris

1158 30, 201-204.

1159

1160 Moreno-Bedmar, J.A., Garcia, R., 2011. Análisis bioestratigráfico de los ammonoideos del

1161 Aptiense inferior (Cretácico Inferior) del Miembro Cap de Vinyet (Formación Margas del

1162 Forcall) de la subcuenca de Morella (Castellón). Consideraciones sobre el límite Barremiense-

1163 Aptiense. In: Pérez-García, A., Gascó, F., Gasulla, J.M., Escaso, F. (Eds.), Viajando a

1164 Mundos Pretéritos. Ayuntamiento de Morella, Morella, Castellón, 215-222.

1165

1166 Moreno-Bedmar, J.A., Barragán, R., Delanoy, G., Company, M., Salas, R., 2014. Review of

1167 the early Aptian (Early Cretaceous) ammonoid species Deshayesites deshayesi (d'Orbigny,

1168 1841). Cretaceous Research 51, 341-360.

1169

1170 Moullade, M., Tronchetti, G., Granier, B., Bornemann, A., Kuhnt, W., Lorenzen; J., 2015.

1171 High-resolution integrated stratigraphy of the OAE1a and enclosing strata from core drillings

1172 in the Bedoulian stratotype (Roquefort-La Bédoule, SE France). Cretaceous Research 56,

1173 119-140.

1174 
1175 Murat, B., 1983. Contribution à l'étude stratigraphique, sedimentologique et tectonique du

1176 bassin éocrétace d'Oliete (Prov. de Teruel, Espagne). PhD thesis, Université Paul Sabatier,

1177 Tolouse, $247 \mathrm{p}$.

1178

1179 Mutterlose, J., Bodin, S., Fähnrich, L., 2014. Strontium-isotope stratigraphy of the Early

1180 Cretaceous (Valanginian-Barremian): Implications for Boreal-Tethys correlation and

1181 paleoclimate. Cretaceous Research 50, 252-263.

1182

1183 Pardo, G., 1979. Estratigrafía y sedimentología de las formaciones detríticas del Cretácico

1184 inferior terminal del Bajo Aragón Turolense. PhD thesis, Universidad de Zaragoza, 473 p.

1185

1186 Pardo, G., Villena, J., 1979. Características sedimentológicas y paleogeográficas de la Fm.

1187 Escucha. Cuadernos de Geología Ibérica 5, 407-418.

1188

1189 Pascual-Cebrian, E., 2014. Shell evolution of the Polyconitidae during the Aptian of Iberia: A

1190 grinding tomography method to map calcite/aragonite fluctuations in rudist bivalves. $\mathrm{PhD}$

1191 thesis, Universität Heidelberg, 144 p.

1192

1193 Pérez-García, A., Ortega, F., Gasulla, J.M., 2009. Revisión histórica y sistemática del primer

1194 hallazgo de tetanuros basales (Theropoda) del Cretácico Inferior de Morella (Castellón).

1195 Geogaceta 47, 21-24.

1196

1197 Pérez-García, A., Gasulla, J.M., Ortega, F., 2014. Eodortoka morellana gen. et sp. nov., the

1198 first pan-pleurodiran turtle (Dortokidae) defined in the Lower Cretaceous of Europe.

1199 Cretaceous Research 48, 130-138. 
1201 Peropadre, C., 2012. El Aptiense del margen occidental de la cuenca del Maestrazgo: 1202 controles tectónico, eustático y climático en la sedimentación. PhD thesis, Universidad 1203 Complutense de Madrid, 649 p.

1204

1205 Peyrot, D., Rodríguez-López, J.P., Barrón, E., Meléndez, N., 2007. Palynology and 1206 biostratigraphy of the Escucha Formation in the Early Cretaceous Oliete sub-basin, 1207 Teruel, Spain. Revista Española de Micropaleontología 39, 135-154.

1208

1209 Pictet, A., Delanoy, G., Adatte, T., Spangenberg, J.E., Baudouin, C., Boselli, P., Boselli, M., 1210 Kindler, P., Föllmi, K.B., 2015. Three successive phases of platform demise during the 1211 early Aptian and their association with the oceanic anoxic Selli episode (Ardèche,

1212 France). Palaeogeography, Palaeoclimatology, Palaeoecology 418, 101-125.

1213

1214 Querol, X., 1990. Distribución de la materia mineral y azufre en los carbones de la Fm.

1215 Escucha. Relación con los factores geológicos, sedimentológicos y diagenéticos. PhD thesis, 1216 Universitat de Barcelona, 509 p.

1217

1218 Querol, X., Salas, R., Pardo, G., Ardèvol, L., 1992. Albian coal-bearing deposits of the 1219 Iberian Range in northeastern Spain. In: McCabe, P.J., Parrish, J.T. (Eds.), Controls on the 1220 distribution and quality of Cretaceous coals. Geological Society of America Special Paper $1221 \quad 267,193-208$.

1223 Reboulet, S., Rawson, P.F., Moreno-Bedmar, J.A., Aguirre-Urreta, M.B., Barragán, R., 1224 Bogomolov, Y., Company, M., González-Arreola, C., Stoyanova, V.I., Lukeneder, A., 
1225 Matrion, B., Mitta, V., Randrianaly, H., Vasicek, Z., Baraboshkin, E.J., Bert, D., Bersac, S.,

1226 Bogdanova, T.N., Bulot, L.G., Latil, J.-L., Mikhailova, I.A., Ropolo, P., Szives, O., 2011.

1227 Report on the 4th International Meeting of the IUGS Lower Cretaceous Ammonite Working

1228 Group, the "Kilian Group" (Dijon, France, 30th August 2010). Cretaceous Research 32, 786-

1229793.

1230

1231 Reboulet, S., Szives, O., Aguirre-Urreta, B., Barragán, R., Company, M., Idakieva, V.,

1232 Ivanov, M., Kakabadze, M.V., Moreno-Bedmar, J.A., Sandoval, J., Baraboshkin, E.J., Çaglar,

1233 M.K., Főzy, I., González-Arreola, C., Kenjo, S., Lukeneder, A., Raisossadat, S.N., Rawson,

1234 P.F., Tavera, J.M., 2014. Report on the 5th International Meeting of the IUGS Lower

1235 Cretaceous Ammonite Working Group, the Kilian Group (Ankara, Turkey, 31st August

1236 2013). Cretaceous Research 50, 126-137.

1237

1238 Ropolo, P., Gonnet, R., Conte, G., 1999. The "Pseudocrioceras interval" and adjacent beds at

1239 La Bédoule (SE France): implications to highest Barremian/lowest Aptian biostratigraphy.

1240 Scripta Geologica, Special Issue 3, 159-213.

1241

1242 Ropolo, P., Conte, G., Gonnet, R., Masse, J.-P., Moullade, M., 2000. Les faunes

1243 d'Ammonites du Barrémien supérieur/Aptien inférieur (Bédoulien) dans la région

1244 stratotypique de Cassis-La Bédoule (SE France): état des connaissances et propositions pour

1245 une zonation par Ammonites du Bédoulien-type. Géologie Méditerranéenne 25, 167-175.

1246

1247 Sahagian, D., Pinous, O., Olferiev, A., Zakharov, V., 1996. Eustatic curve for the Middle

1248 Jurassic-Cretaceous based on Russian Platform and Siberian stratigraphy: zonal resolution.

1249 AAPG Bulletin 80, 1433-1458. 
1251 Salas, R., 1987. El Malm i el Cretaci inferior entre el Massís de Garraf i la Serra d'Espadà.

1252 Anàlisi de Conca. $\mathrm{PhD}$ thesis, Universitat de Barcelona, 345 p.

1253

1254 Salas, R., Guimerà, J., Mas, R., Martín-Closas, C., Meléndez, A., Alonso, A., 2001. Evolution 1255 of the Mesozoic Central Iberian Rift System and its Cainozoic inversion (Iberian Chain). In: 1256 Ziegler, P.A., Cavazza, W., Roberston, A.H.F., Crasquin-Soleau, S. (Eds.), Peri-Tethys 1257 Memoir 6: Peri-Tethyan Rift/Wrench Basins and Passive Margins. Mémoires du Muséum 1258 National d'Histoire Naturelle, Paris 186, 145-186.

1260 Salas, R., Casas, A., 1993. Mesozoic extensional tectonics, stratigraphy, and crustal evolution 1261 during the Alpine cycle of the eastern Iberian basin. Tectonophysics 228, 33-55.

1262

1263 Salas, R., Martín-Closas, C., Querol, X., Guimerà, J., Roca, E., 1995. In: Salas, R., Martín1264 Closas, C. (Eds.), El Cretácico inferior del nordeste de Iberia. Publicacions de la Universitat 1265 de Barcelona, 13-94.

Salas, R., Guimerà, J., 1996. Rasgos estructurales principales de la cuenca Cretácica Inferior del Maestrazgo (Cordillera Ibérica oriental). Geogaceta 20, 1704-1706.

1270 Schlagintweit, F., Bover-Arnal, T., Salas, R., 2010. Erratum to: New insights into 1271 Lithocodium aggregatum Elliott 1956 and Bacinella irregularis Radoičić 1959 (Late JurassicLower Cretaceous): two ulvophycean green algae (?Order Ulotrichales) with a heteromorphic life cycle (epilithic/euendolithic). Facies 56, 635-673. 
1275 Schlagintweit, F., Bover-Arnal, T., 2012. The morphological adaption of Lithocodium 1276 aggregatum Elliott (calcareous green alga) to cryptic microhabitats (Lower Aptian, Spain): an example of phenotypic plasticity. Facies 58, 37-55

1278

Schlagintweit, F., Bover-Arnal, T., 2013. Remarks on Bacinella Radoicic, 1959 (type species B. irregularis) and its representatives. Facies 59, 59-73

1281

1282

Schroeder, R., van Buchem, F.S.P., Cherchi, A., Baghbani, D., Vincent, B., Immenhauser, A.,

Granier, B., 2010. Revised orbitolinid biostratigraphic zonation for the Barremian - Aptian of the eastern Arabian Plate and implications for regional stratigraphic correlations. In: van Buchem, F.S.P., Al-Husseini, M.I., Maurer, F., Droste, H.J. (Eds.), Barremian - Aptian Stratigraphy and Hydrocarbon Habitat of the Eastern Arabian Plate. GeoArabia Special Publication 4, Gulf PetroLink, Bahrain 1, 49-96.

Schroeder, R., 1964. Orbitoliniden-biostratigraphie des Urgons nordöslich von Teruel (Spanien). Neues Jahrbuch für Geologie und Paläontologie. Monatshefte 8, 462-474.

Skelton, P.W., Gili, E., 2012. Rudists and carbonate platforms in the Aptian: a case study on biotic interactions with ocean chemistry and climate. Sedimentology 59, 81-117.

Skelton, P.W., Gili, E., Bover-Arnal, T., Salas, R., Moreno-Bedmar, J.A., 2010. A new 1296 species of Polyconites from the uppermost Lower Aptian of Iberia and the early evolution of polyconitid rudists. Turkish Journal of Earth Sciences 19, 557-572. 
1299 Solé de Porta, N., Salas, R., 1994. Conjuntos microflorísticos del Cretácico inferior de la

1300 Cuenca del Maestrazgo. Cordillera Ibérica Oriental (NE de España). Cuadernos de Geología

1301 Ibérica 18, 355-368.

1302

1303 Solé de Porta, N., Querol, X., Cabanes, R., Salas, R., 1994. Nuevas aportaciones a la

1304 palinología y paleoclimatología de la Formación Escucha (Albiense inferior-medio) en las

1305 Cubetas de Utrillas y Oliete. Cordillera Ibérica Oriental. Cuadernos de Geología Ibérica 18,

$1306 \quad 203-215$.

1307

1308 Sornay, J., Marin, P., 1972. Sur la faune d'ammonites aptiennes de la Tejeria de Josa (Teruel,

1309 Espagne). Annales de Paléontologie (Invertébrés), t. LVIII, 101-114.

1310

1311 Suarez-Gonzalez, P., Quijada, I.E., Benito, M.I., Mas, R., 2013. Eustatic versus tectonic

1312 control in an intraplate rift basin (Leza Fm, Cameros Basin). Chronostratigraphic and

1313 paleogeographic implications for the Aptian of Iberia. Journal of Iberian Geology 39, 285-

1314312.

1315

1316 Stein, M., Arnaud-Vanneau, A., Adatte, T., Fleitmann, D., Spangenberg, J.E. and Föllmi,

1317 K.B., 2012. Palaeoenvironmental and palaeoecological change on the northern Tethyan

1318 carbonate platform during the Late Barremian to earliest Aptian. Sedimentology 59, 939-963.

1319

1320 Steuber, T., 1999. Isotopic and chemical intra-shell variations in low-Mg calcite of rudist

1321 bivalves (Mollusca: Hippuritacea): disequilibrium fractionations and Late Cretaceous

1322 seasonality. International Journal Earth Sciences 88, 551-570.

1323 
1324 Steuber, T., 2001. Strontium isotope stratigraphy of TuronianeCampanian Gosau-type rudist

1325 formations in the Northern Calcareous and Central Alps (Austria and Germany). Cretaceous

1326 Research 22, 429-441.

1328 Steuber, T., 2003a. Strontium isotope chemostratigraphy of rudist bivalves and cretaceous

1329 carbonate platforms. In: Gili, E., Negra, M.E.H., Skelton, P.W. (Eds.), North African

1330 Cretaceous Carbonate Platform Systems, NATO Science Series, IV. Earth and Environmental

1331 Sciences 28, 229-238.

1332

1333 Steuber, T., 2003b. Strontium isotope stratigraphy of Cretaceous hippuritid rudist bivalves:

1334 rates of morphological change and heterochronic evolution. Palaeogeography,

1335 Palaeoclimatology, Palaeoecology 200, 221-243.

1336

1337 Steuber, T., Schlüter, M., 2012. Strontium-isotope stratigraphy of Upper Cretaceous rudist

1338 bivalves: biozones, evolutionary patterns and sea-level change calibrated to numerical ages.

1339 Earth-Science Reviews 114, 42-60.

1340

1341 Steuber, T., Korbar, T., Jelaska, V., Gusic, I., 2005. Strontium isotope stratigraphy of Upper

1342 Cretaceous platform carbonates of the island of Brac (Adriatic Sea, Croatia): implications for

1343 global correlation of platform evolution and biostratigraphy. Cretaceous Research 26, 7411344756.

1345

1346 Tomás, S., Löser, H., Salas, R., 2008. Low-light and nutrient-rich coral assemblages in an

1347 Upper Aptian carbonate platform of the southern Maestrat Basin (Iberian Chain, eastern

1348 Spain). Cretaceous Research 29, 509-534. 
1350 Vail, P.R., Audemard, F., Bowman, S.A., Eisner, P.N., Perez-Cruz, C., 1991. The

1351 stratigraphic signatures of tectonics, eustasy and sedimentology - an overview. In: Einsele, G.,

1352 Ricken, W., Seilacher, A. (Eds.), Cycles and Events in Stratigraphy, Springer, Berlin,

$1353 \quad 617-659$.

1354

1355 Vennin, E., Aurell, M., 2001. Stratigraphie sequentielle de l'Aptien du sous-basin de Galvé 1356 (Province de Teruel, NE de l'Espagne). Bulletin de la Société Géologique de France 172, $1357 \quad 397-410$.

1359 Vicedo, V., Frijia, G., Parente, M., Caus, E., 2011. The late Cretaceous genera Cuvillierinella, 1360 Cyclopseudedomia and Rhapydionina (Rhapydioninidae, Foraminiferida) in shallow water 1361 carbonates of Pylos (Peloponnese, Greece). Journal of Foraminiferal Research 41, 41-52.

1362

1363 Vilas, L., Masse, J.P., Arias, C., 1995. Orbitolina episodes in carbonate platform evolution: 1364 the early Aptian model from SE Spain. Palaeogeography, Palaeoclimatology, Palaeoecology, $1365119,35-45$.

1366

1367 Villanueva-Amadoz, U., Pons, D., Diez, J. B., Ferrer, J., Sender, L.M., 2010. Angiosperm 1368 pollen grains of Sant Just site (Escucha Formation) from the Albian of the Iberian Range 1369 (north-eastern Spain). Review of Palaeobotany and Palynology 162, 362-381.

1371 Villanueva-Amadoz, U., Santisteban, C., Santos-Cubedo, A., 2014. Age determination of the 1372 Arcillas de Morella Formation (Maestrazgo Basin, Spain), Historical Biology 27, 389-397. 
1374 Wagreich, M., Hohenegger, J., Neuhuber, S., 2012. Nannofossil biostratigraphy, strontium

1375 and carbon isotope stratigraphy, cyclostratigraphy and an astronomically calibrated duration

1376 of the Late Campanian Radotruncana calcarata Zone. Cretaceous Research 38, 80-96.

1378 Weisser, D., 1959. Acerca de la estratigrafía del Urgo-Aptense en las cadenas Celtibericas de 1379 España. Notas y Comunicaciones del Instituto Geológico y Minero de España 55, 17-32.

1381 Williamson, T., Henderson, R.A., Price, G.D., Collerson, K.D., 2012. Strontium-isotope

1382 stratigraphy of the Lower Cretaceous of Australia. Cretaceous Research 36, 24-36.

1384 Wissler, L., Funk, H., Weissert, H., 2003. Response of Early Cretaceous carbonate platforms 1385 to chages in atmospheric carbon dioxide levels. Palaeogeography, Palaeoclimatology, 1386 Palaeoecology 200, 187-205.

1388 Yagüe, P., Ortega, F., Noé, L.F., Gasulla, J.M., García, M.D., 2003. Reptiles marinos

1389 (Plesiosauria) del Aptiense inferior de Morella (Castellón). In: Perez-Lorente, F. (Coord.),

1390 Dinosaurios y otros reptiles mesozoicos de España. Ciencias de la Tierra, Logroño 26, 3991391404.

1393 Zalasiewicz, J., Smith, A., Brenchley, P., Evans, J., Knox, R., Riley, N., Gale, A., Gregory, 1394 F.J., Rushton, A., Gibbard, P., Hesselbo, S., Marshall, J., Oates, M., Rawson, P., Trewin, N., 1395 2004. Simplifying the stratigraphy of time. Geology 32, 1-4. 
1399 Figure 1. A) Map of the Iberian Peninsula with the situation of the Maestrat Basin in the 1400 eastern part of the Iberian Chain. B) Schematic palaeogeographical map of the Maestrat Basin 1401 during the Late Jurassic-Early Cretaceous extensional period subdivided into its seven sub1402 basins, namely Oliete (Ol), Aliaga (Al), Galve (Ga), Penyagolosa (Pg), Morella (Mo), El 1403 Perelló (Pe) and Salzedella (Sa). Modified after Salas et al. (2001). Sampling locations for Sr1404 isotope stratigraphy are marked with a circle. See Fig. 4 for key. The location of the 1405 ammonite Martelites sp. found during the writing of this study is marked with a red star.

1407 Figure 2. Litho-stratigraphic framework of the Late Barremian-Early Aptian sedimentary 1408 record of the Maestrat Basin showing the classical (black arrows A1-A2) and this study's 1409 (black arrow B) stratigraphic positions of the Barremian-Aptian boundary. See Fig. 4 for key.

1411 Figure 3. Chrono-stratigraphic chart for the Barremian-Early Albian of the Maestrat Basin

1412 including the more relevant ammonoid, orbitolinid and rudist occurrences, Sr-derived 1413 numerical ages, major transgressive-regressive sequences and lithostratigraphic units. The 1414 ranges of the fossils are facies and stratigraphically constrained to their occurrences in the 1415 sections studied in the Maestrat Basin by Weisser (1959), Schroeder (1964), Aguilar et al. 1416 (1971), Marin and Sornay (1971), Sornay and Marin (1972), Canérot et al. (1982), Salas 1417 (1987), Martínez et al. (1994), López Llorens (2007), Moreno-Bedmar et al. (2008, 2009a, b, 1418 2010a, b, 2012, 2014), Tomás et al. (2008), Bover-Arnal et al. (2009, 2010, 2011a, b, 2012, 1419 2014, 2015), Moreno-Bedmar (2010), Schlagintweit et al. (2010), Skelton et al. (2010), 1420 Moreno-Bedmar and Garcia (2011), Peropadre (2012), Schlagintweit and Bover-Arnal 1421 (2012), Skelton and Gili (2012), Martín-Martín et al. (2013), Pascual-Cebrian (2014) and 1422 Garcia et al. (2014). Numerical ages, geo-magnetic polarity intervals and ammonite zones are 1423 taken from Gradstein et al. (2004). Barremian-Early Albian sequence-stratigraphic framework 
1424 of European basins is characterized in Hardenbol et al. (1998), and tied to numerical ages in

1425 Gradstein et al. (2004). The ammonite zones identified are dashed in grey. Different species 1426 and corresponding ranges are distinguished by using different colours. The Barremian

1427 Camarillas and Cantaperdius formations are outside the scope of this paper and are thus not 1428 detailed in the figure. The Camarillas Formation mainly consists of continental clastics, and 1429 the Cantaperdius Formation is formed by lacustrine limestones and marls. See Fig. 4 for key.

$1431 \quad$ Figure 4. Key to Figure 3.

1433 Figure 5. Lithostratigraphy and major transgressive-regressive cycles of the Late Barremian

1434 sedimentary record of the Maestrat Basin. A) Panoramic view of the Late Barremian Artoles, 1435 Morella and Xert lithostratigraphic units cropping out along the Barranco de las Calzadas 1436 section (see Bover-Arnal et al. 2010 for situation), $500 \mathrm{~m}$ to the west of the village of

1437 Miravete de la Sierra (Comarca of El Maestrazgo) in the Galve sub-basin (Fig. 1B). The first 1438 major transgressive-regressive sequence and the lowermost part of the transgressive unit of 1439 Sequence II are indicated. Note the reddish colour (continental record) mainly exhibited by 1440 the Morella Formation and the bluish colour (marine record) shown by the Artoles and Xert 1441 formations. Width of image is $c .280 \mathrm{~m}$. See Fig. 4 for legend. B) Outcrop view of the Late

1442 Barremian Morella Formation. The transgressive-regressive sequence-stratigraphic

1443 interpretation is indicated. Note the reddish colour (continental record) of the succession

1444 below the sharp to slightly erosive transgressive surface (TS), and how above this surface the

1445 Morella Formation exhibits a bluish colour (marine record). The quarry pit where this photo 1446 was taken is located in the Morella sub-basin (Fig. 1B), $4 \mathrm{~km}$ to the southwest of the town of 1447 Morella (Comarca of Els Ports). Width of image is $c .60$ m. See Fig. 4 for legend. C) Outcrop 1448 view of the Late Barremian transitional Cervera del Maestrat Formation. The abandoned 
1449 quarry pit where this photo was taken is located in the Salzedella sub-basin (Fig. 1B), $1.2 \mathrm{~km}$

1450 to the northeast of the town of Cervera del Maestrat (Comarca of El Baix Maestrat). Width of 1451 image is $c .35 \mathrm{~m}$.

1453 Figure 6. Lithostratigraphy and major transgressive-regressive cycles of the Late Barremian1454 Late Aptian sedimentary record of the Maestrat Basin. A) Panoramic view of the Late 1455 Barremian-latest Aptian Penyagolosa section (see Salas 1987 and Salas et al. 1995 for 1456 situation) including the transgressive-regressive sequence-stratigraphic interpretation. This 1457 section, which gives rise to the Penyagolosa Massif, crops out $5 \mathrm{~km}$ to the northeast of the 1458 town of Villafermosa (Comarca of l'Alt Millars), in the Penyagolosa sub-basin (Fig. 1B).

1459 Width of image is $c .3 .7 \mathrm{~km}$. TS=Transgressive surface; MFS=Maximum flooding surface.

1460 See Fig. 4 for legend. B) Panoramic view of the Mola de Xert located $1.5 \mathrm{~m}$ to the north of 1461 the town of Xert (Comarca of El Baix Maestrat). The limestones of the Late Barremian Xert

1462 Formation and the marls and platform carbonates of the Early Aptian Forcall and Villarroya 1463 de los Pinares formations, respectively, can be easily recognized. The transgressive-regressive 1464 sequence stratigraphic interpretation is indicated. Width of image is $c .1 .4 \mathrm{~km}$. See Fig. 4 for

1465 legend. C) Outcrop view of Sequence II, which includes the Xert, Forcall and Villarroya de 1466 los Pinares formations, at the northern entrance to the town of Villarroya de los Pinares 1467 (Comarca of El Maestrazgo), in the Galve sub-basin (Fig. 1B). The transgressive-regressive 1468 sequence-stratigraphic interpretation is indicated. Width of image is c. $200 \mathrm{~m}$. See Fig. 4 for 1469 legend.

1471 Figure 7. Lithostratigraphy and major transgressive-regressive cycles of the Late Barremian1472 Late Aptian sedimentary record of the Maestrat Basin. A) Panoramic photo showing the latest 1473 Barremian-early Late Aptian lithostratigraphy of the Maestrat Basin including the Xert, 
1474 Forcall, Villarroya de los Pinares and Benassal (lower part) formations. The transgressive-

1475 regressive sequence-stratigraphic interpretation is indicated. This succession is exposed along

1476 the eastern limb of the Camarillas syncline, which is located to $3.5 \mathrm{~km}$ the northwest of the

1477 viallage of Miravete de la Sierra (Comarca of El Maestrazgo), in the Galve sub-basin (Fig.

1478 1B). Width of image is $c .450 \mathrm{~m}$. TS=Transgressive surface; MFS=Maximum flooding

1479 surface. See Fig. 4 for legend. B) Field view of the Early Aptian Forcall Formation cropping

1480 out in El Perelló sub-basin (Fig. 1B). The photo was taken along the highway A7 in a road cut

1481 located $2 \mathrm{~km}$ to the northeast of the town of El Perelló (Comarca of El Baix Ebre). Geologist

1482 at left for scale is $1.61 \mathrm{~m}$ tall without boots. C) Field view of sequences II and III including

1483 the Forcall, Villarroya de los Pinares and Benassal formations. The transgressive-regressive

1484 sequence-stratigraphic interpretation is indicated. This hillock (La Mola d'en Camaràs; see

1485 Bover-Arnal et al. 2014) is located $1.3 \mathrm{~km}$ to the northeast of the town of El Forcall (Comarca

1486 of Els Ports), in the Morella sub-basin (Fig. 1B). Width of image is c. $25 \mathrm{~m}$.

1487 TS=Transgressive surface; MFS=Maximum flooding surface. See Fig. 4 for legend. D)

1488 Outcrop view of Sequence III, which corresponds to the lower part of the Benassal Formation.

1489 The transgressive-regressive sequence-stratigraphic interpretation is indicated. This outcrop is

1490 located in the Barranco de las Corralizas section (see Bover-Arnal et al. 2010 for situation; 1491 sample B2 was collected in this locality; Fig. 3 and Table 1), $2.4 \mathrm{~km}$ to the west of the village

1492 of Miravete de la Sierra (Comarca of El Maestrazgo), in the Galve sub-basin (Fig. 1B). Width

1493 of image is $c .350 \mathrm{~m}$.

1494

1495 Figure 8. Lithostratigraphy and major transgressive-regressive cycles of the Late Aptian1496 Early Albian sedimentary record of the Maestrat Basin. A) Field view of the Benassal 1497 Formation, which gives rise to the Orpesa Range between the towns of Orpesa and 1498 Benicàssim (Comarca of La Plana Alta), in the Penyagolosa sub-basin (Fig. 1B). Width of 
1499 image is approximately $4 \mathrm{~km}$. B) Field view of the three transgressive-regressive cycles (III,

1500 IV and V) of the Benassal Formation in the Barranco del Portolés section (see Vennin and 1501 Aurell 2001, Embry et al. 2010 and Bover-Arnal et al. 2010 for situation), located $1.3 \mathrm{~km}$ to 1502 the north of the town of Villarroya de los Pinares (Comarca of El Maestrazgo), in the Galve 1503 sub-basin (Fig. 1B). Width of image is $c .130 \mathrm{~m}$. TS=Transgressive surface; MFS=Maximum 1504 flooding surface. See Fig. 4 for legend. C) Outcrop view of the Albian coal-bearing Escucha 1505 Formation in the environs of the town of Aliaga (Comarca of El Maestrazgo), in the Galve 1506 sub-basin (Fig. 1B). Transgressive unit of Sequence VI. Jacob's staff $=1.5 \mathrm{~m}$.

1508 Figure 9. Martelites sp. Lateral and ventral views of the specimen PUAB 90990 (=PUAB 1509 Collections of Paleontology of the Universitat Autònoma de Barcelona, Bellaterra, Spain), 1510 which was collected in the lower part of the Xert Formation cropping out in Torre Miró (km. 151170 of the N-232 road), in the Morella sub-basin (Fig. 1B). The black arrow indicates the 1512 initial helically coiled whorls that are characteristic of the Family Heteroceratidae. The white 1513 triangles mark the last septa. Scale bar is $1 \mathrm{~cm}$.

\section{Table}

Table 1. A) Analytical results of low-Mg calcite of rudist, oyster and brachiopod shells from 1518 the Maestrat Basin analysed for this study. See Fig. 1B for location of the samples collected. 1519 Numerical ages are derived from McArthur et al. (2001; look-up table version 4; 08/04). 1520 Numerical ages on the left side of the figure are taken from Gradstein et al. (2004). \pm 2 s.e. $=2$ 1521 standard error. na $=$ not applicable; $\mathrm{P}=$ Pristine; $\mathrm{PA}=$ Probably Altered; $\mathrm{A}=$ Altered. The analytical results written in italics were not used to derive numerical ages due to possible

1523 alteration of the sample. The analytical results used to calculate ages are written in bold. B) 
1524 Analytical results of low-Mg calcite of rudist shells from the western Maestrat Basin (Galve 1525 sub-basin; Fig. 1B) obtained by Pascual-Cebrian (2014). Numerical ages are derived from 1526 McArthur et al. (2001; look-up table version 4; 08/04). Numerical ages are taken from 1527 Gradstein et al. (2004). \pm 2 s.e. $=2$ standard error. $\mathrm{P}=$ Pristine; $\mathrm{PA}=$ Probably Altered. 


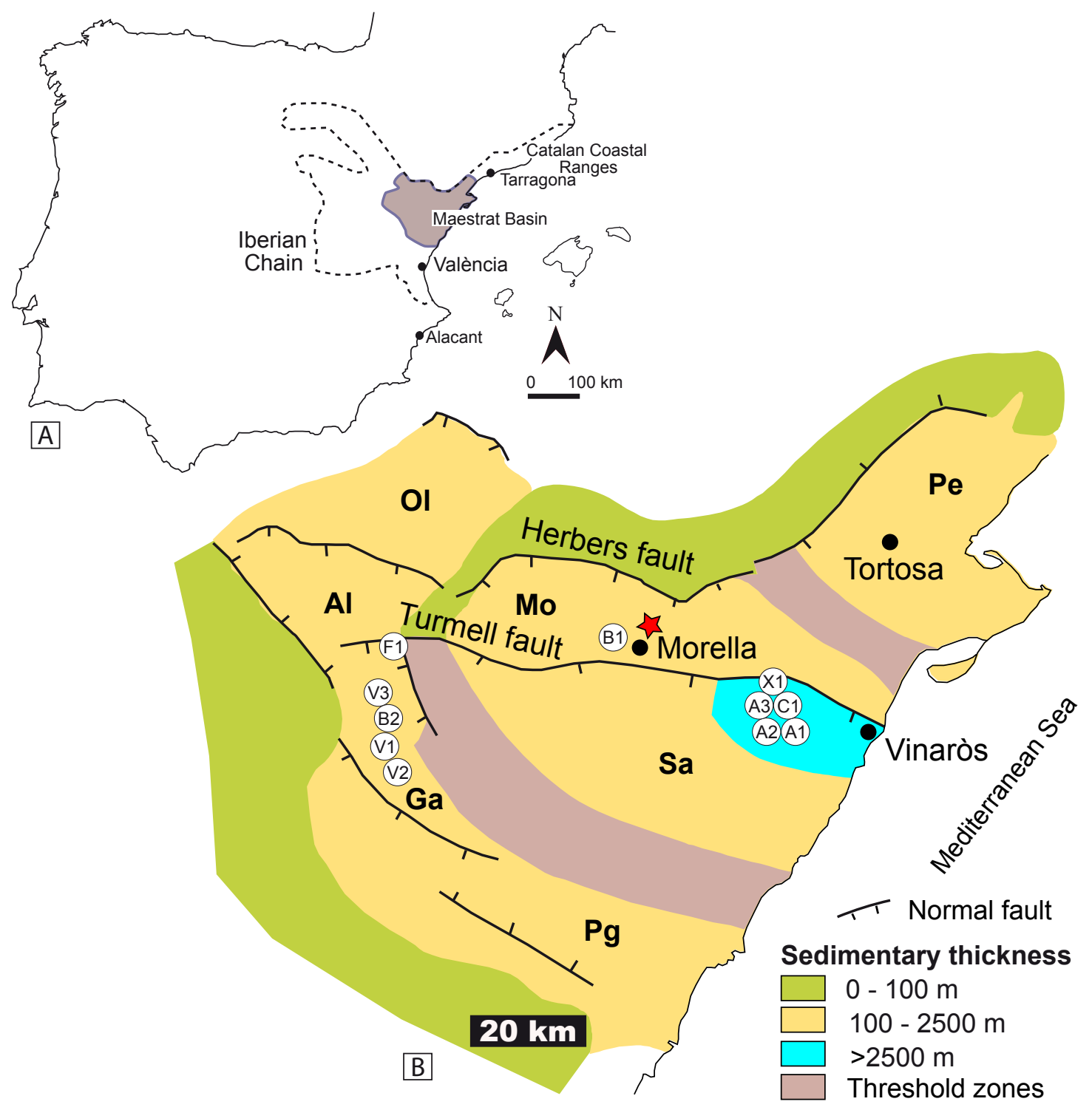




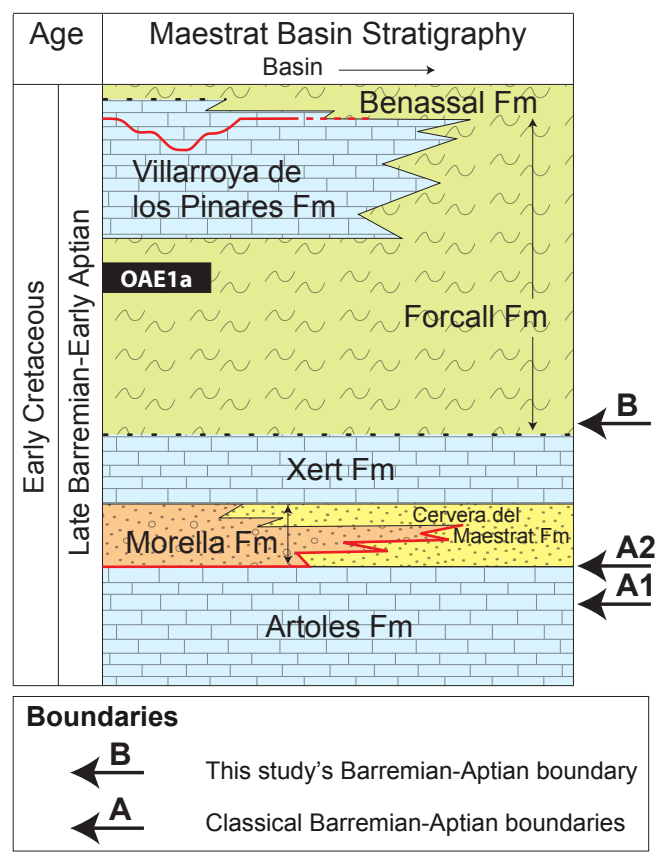




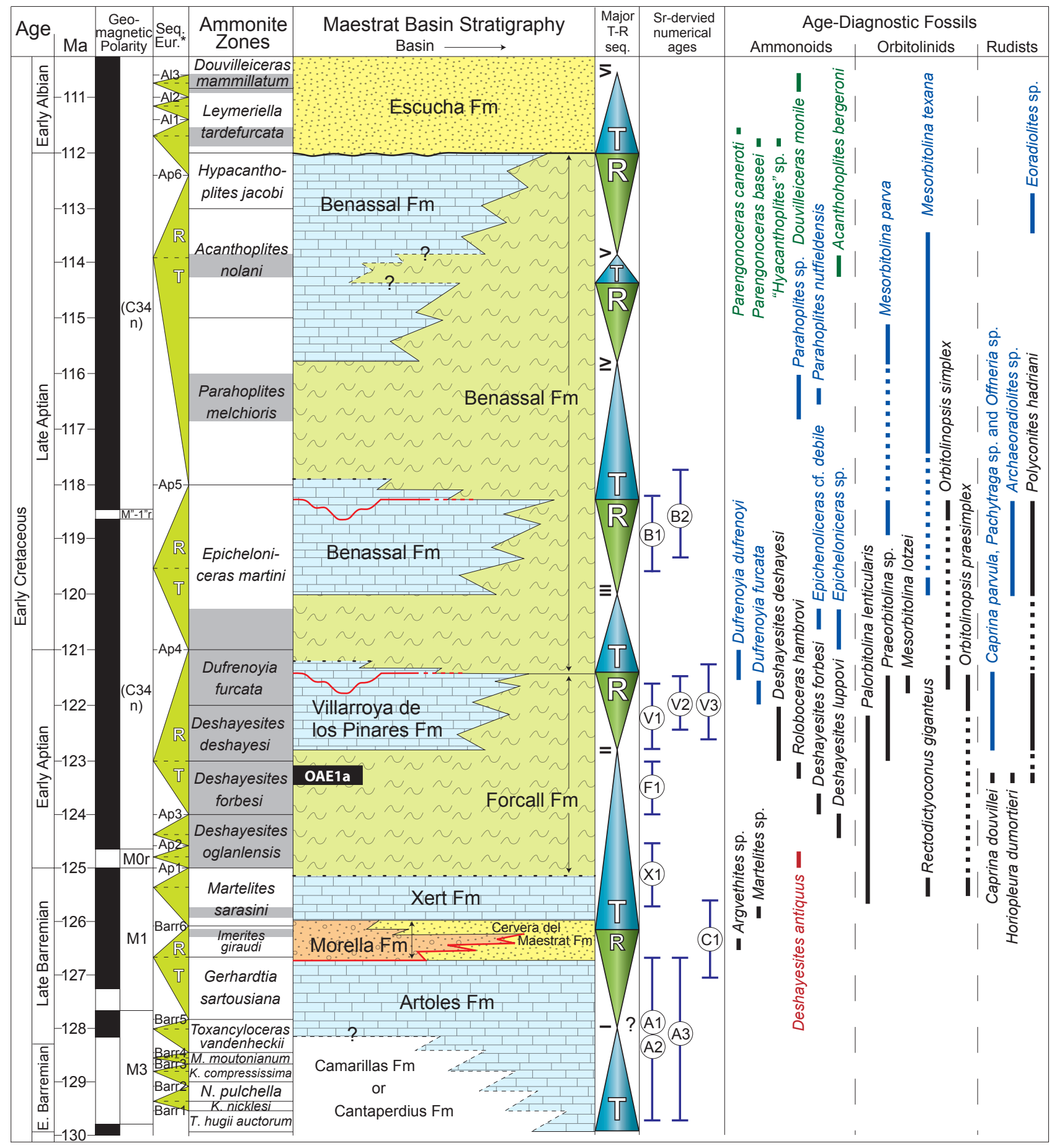




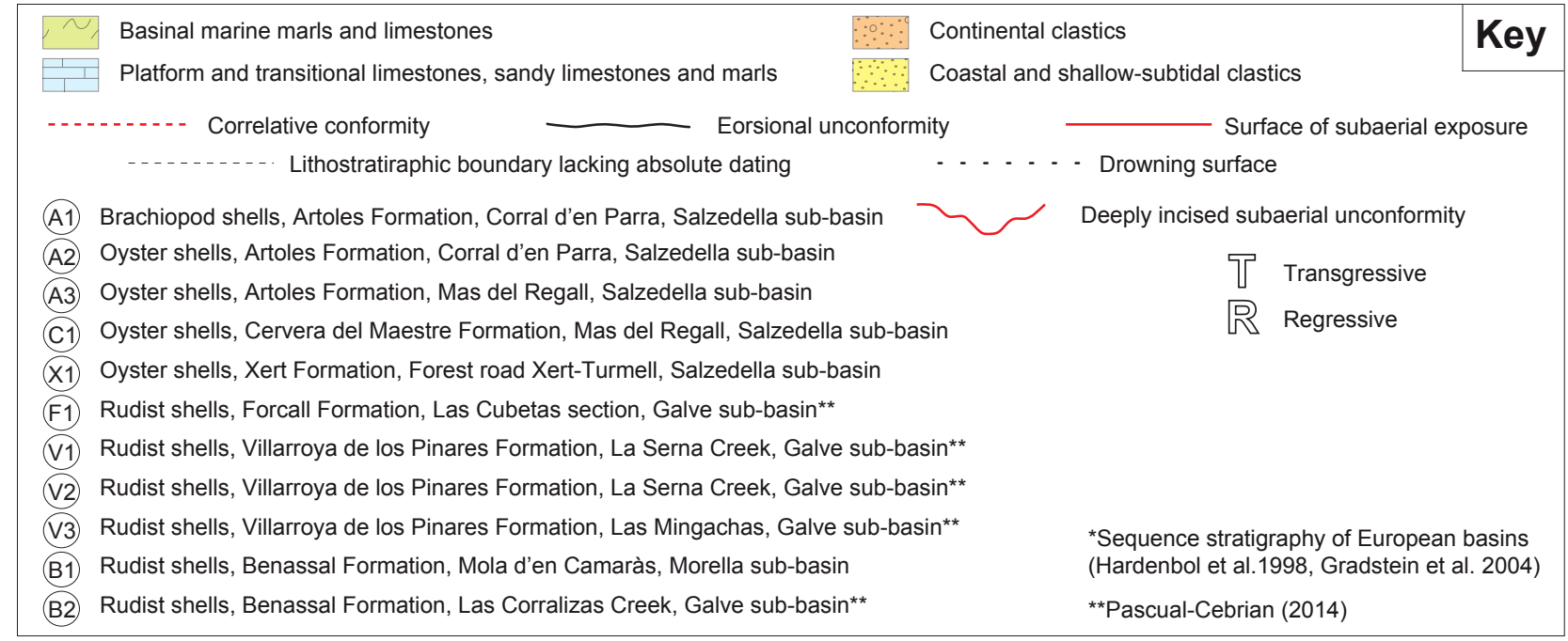




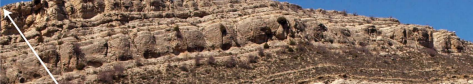

Xert Fm:

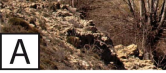

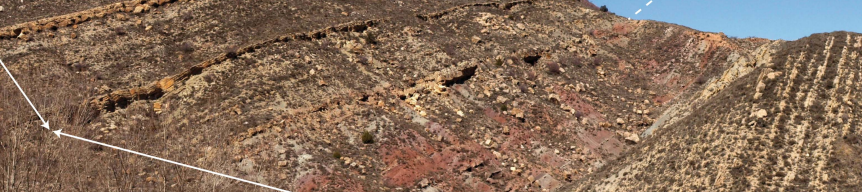




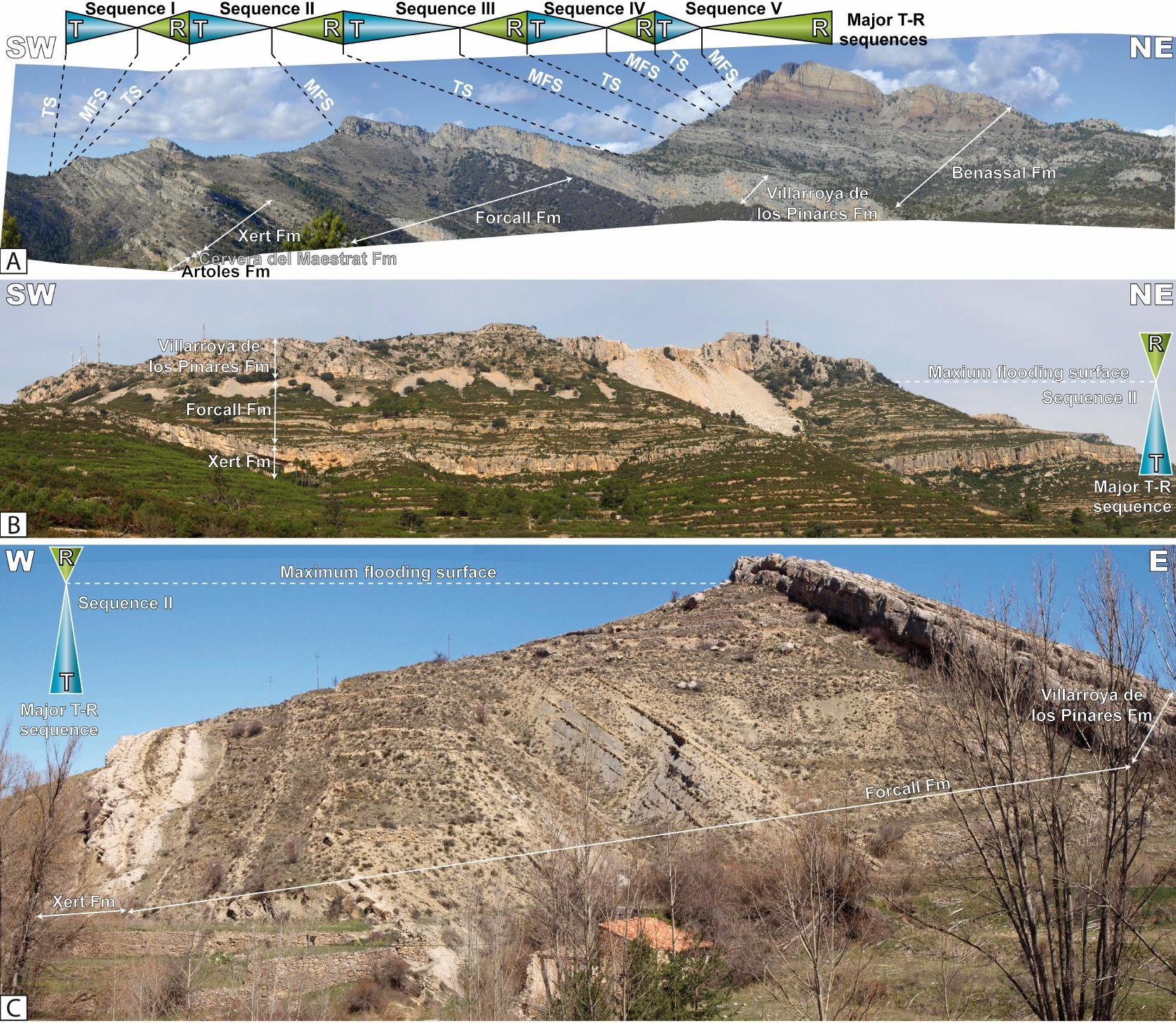




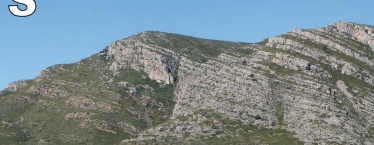

$A-x-5=$
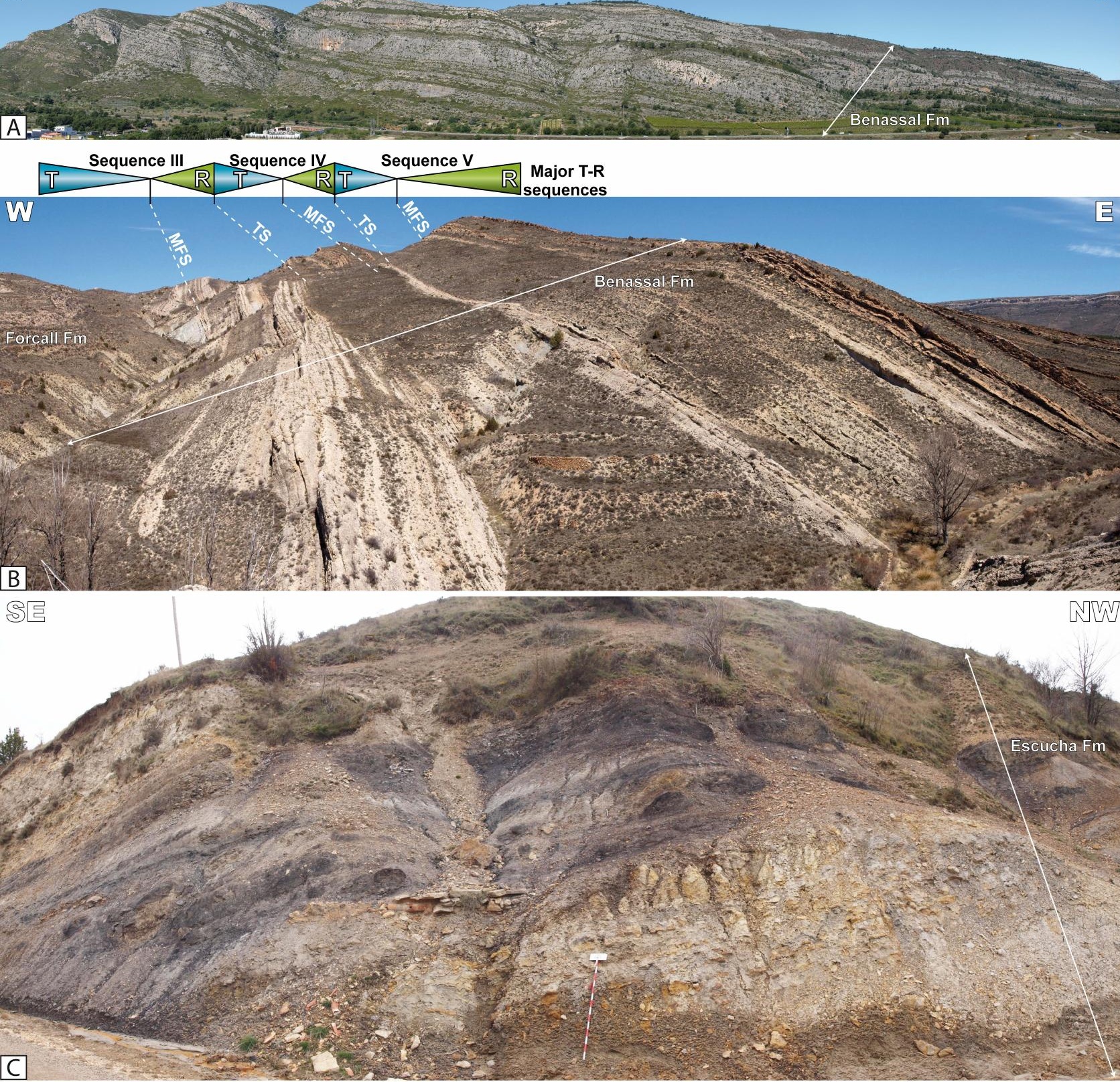


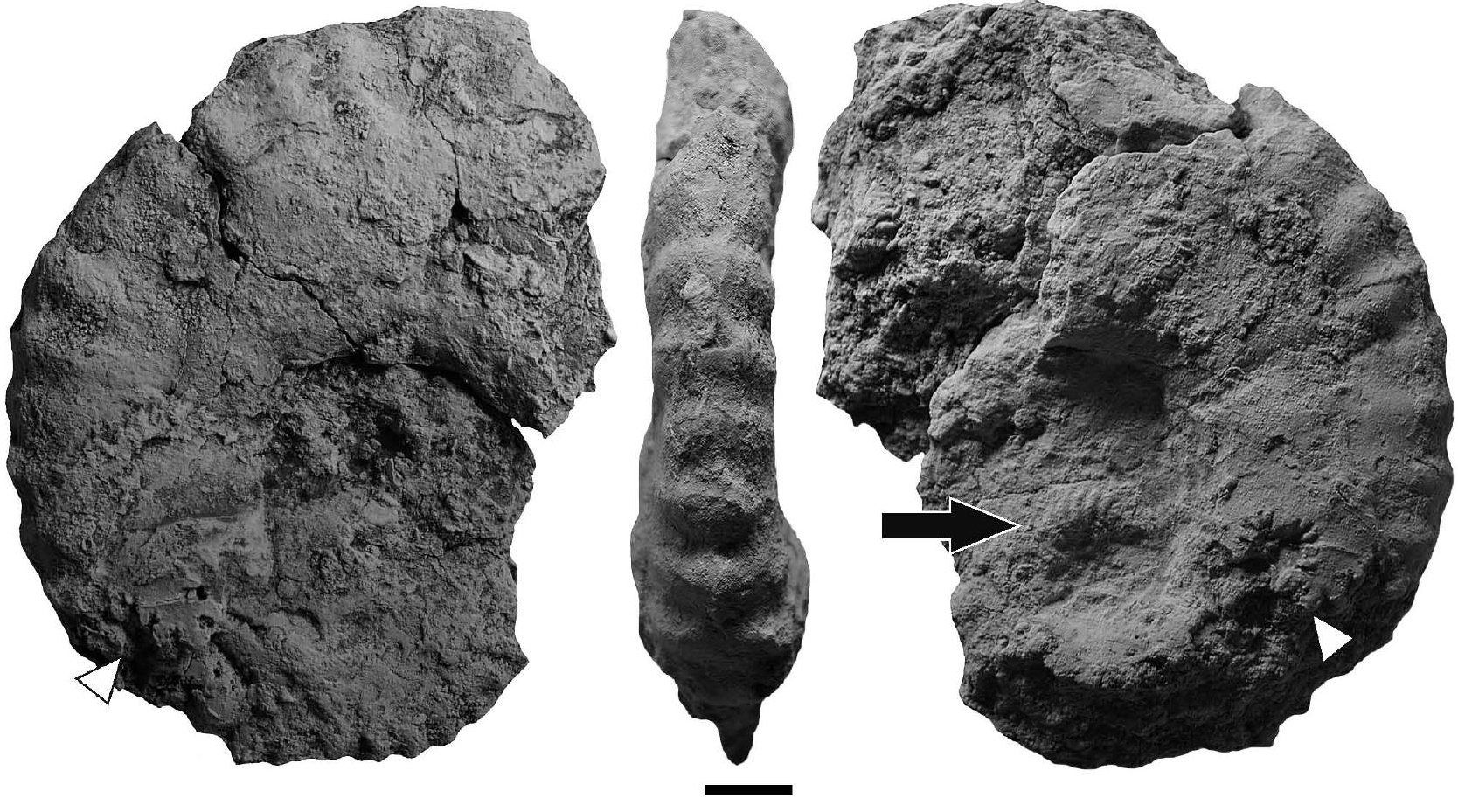




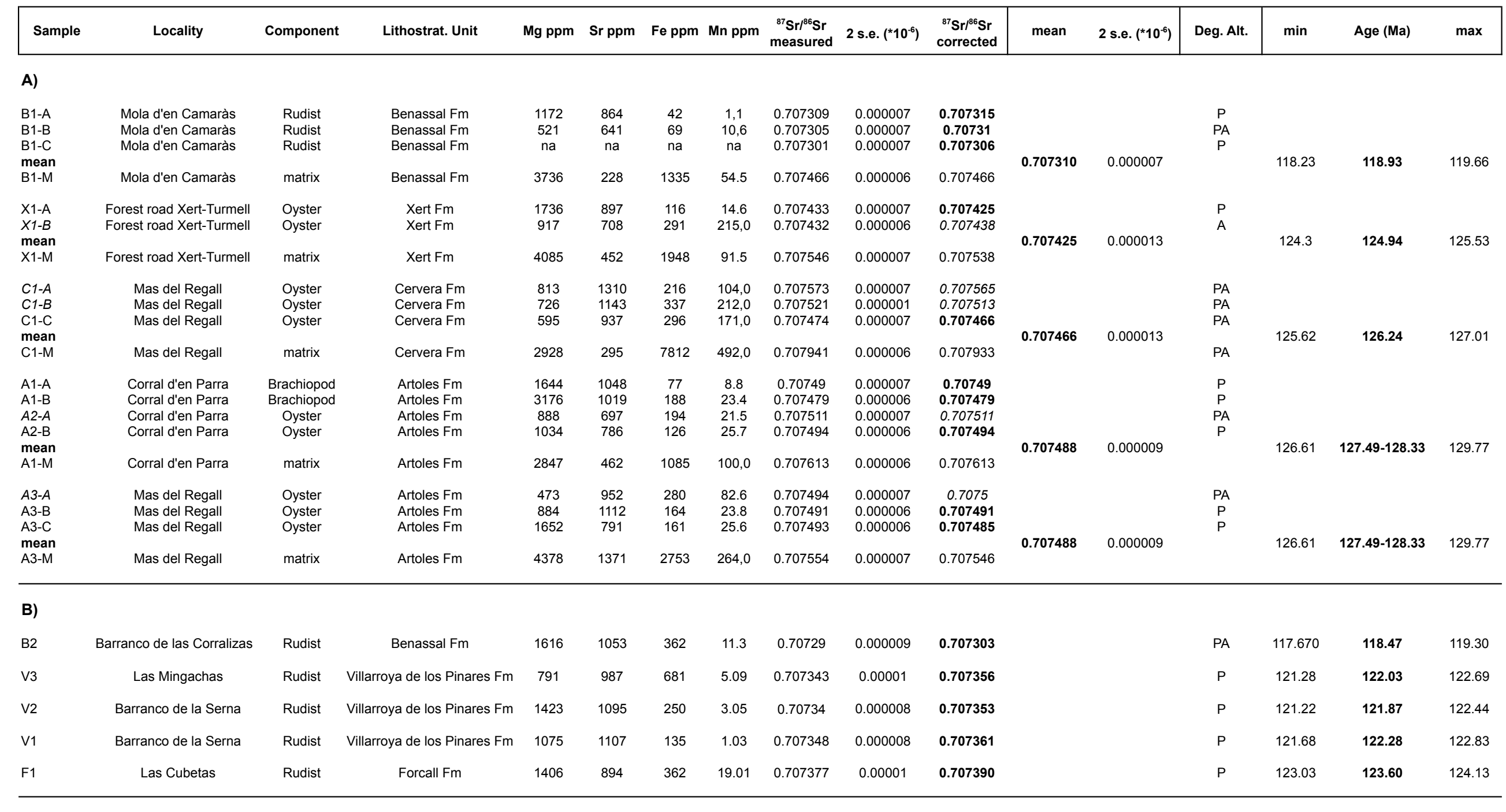

